$1-1-2012$

\title{
Transtemporal Separation of Powers in the Law of Precedent
}

Randy Beck

University of Georgia School of Law, rbeck@uga.edu

b

\section{Repository Citation}

Randy Beck, Transtemporal Separation of Powers in the Law of Precedent , 87 Notre Dame L. Rev. 1405 (2012),

Available at: https://digitalcommons.law.uga.edu/fac_artchop/818

This Article is brought to you for free and open access by the Faculty Scholarship at Digital Commons @ University of Georgia School of Law. It has been accepted for inclusion in Scholarly Works by an authorized administrator of Digital Commons @ University of Georgia School of Law. Please share how you have benefited from this access For more information, please contact tstriepe@uga.edu. 


\title{
TRANSTEMPORAL SEPARATION OF POWERS IN
}

\section{THE LAW OF PRECEDENT}

\author{
Randy Beck*
}

\section{INTRODUCTION}

Judicial power consists of "jurisdiction," the authority to speak (dictio) the law (ius). ${ }^{1}$ As Chief Justice Marshall articulated the judge's role, it is "the province and duty of the judicial department to say what the law is." ${ }^{2}$ In defining the judiciary's "province," Marshall metaphorically staked out a territory in which courts may govern. Within that territory, courts speak the law with authority, resolving disputes and binding other actors.

The metaphor of a judicial "province" carries with it the implication of boundaries to the judge's authority. Courts may speak the law authoritatively only within limits fixed by the Constitution and other legal constraints. Two borders have historically proved especially important in defining judicial power. First, courts may not issue rulings on their own initiative. ${ }^{3}$ They address legal issues only in the course of resolving cases brought to them by others. ${ }^{4}$ Second, in

(C) 2012 Randy Beck. Individuals and nonprofit institutions may reproduce and distribute copies of this Article in any format at or below cost, for educational purposes, so long as each copy identifies the author, provides a citation to the Notre Dame Law Review, and includes this provision in the copyright notice.

* Justice Thomas O. Marshall Chair of Constitutional Law, University of Georgia School of Law. I would like to express my appreciation to John Little, Isaac McAdams and Jason Sheppard for excellent research assistance. Thank you also to Hillel Levin for helpful comments on a draft of this article.

1 See III Oxford Latin Dictionary 538 (1971) (listing “[t] he action of speaking” as the first definition of "dictio"); IV $i d$. at 984 (identifying "iurisdictio" as a combination of "iuris (gen. sg. of $\mathrm{IVS}^{2}$ ) + DICTIO"); IV id. (listing "[t] hat which is sanctioned or ordained, law" as the first definition of "ius").

2 Marbury v. Madison, 5 U.S. (1 Cranch) 137, 177 (1803).

3 See Broadrick v. Oklahoma, 413 U.S. 601, 610-11 (1973) (noting that courts are not "roving commissions" empowered "to pass judgment on the validity of the Nation's laws").

4 See Rebecca Schoff, Note, Deciding on Doctrine: Anti-Miscegenation Statutes and the Development of Equal Protection Analysis, 95 VA. L. Rev. 627, 652 (2009) ("Courts, unlike 
resolving litigated disputes, courts may only properly speak the "law," 5 employing sources and modes of reasoning recognized as "legal." Judges lack the freedom of legislators to pursue unguided policy preferences. ${ }^{6}$

The power of courts to "say what the law is" must be harmonized with the legitimate law-speaking powers of other governmental actors. After all, one might just as properly say that it is "the province and duty of the [legislative] department" to "say what the law is," though at a higher level of generality than courts. ${ }^{7}$ The "executive department" can similarly be thought to speak the law when it issues regulations or resolves administrative proceedings. ${ }^{8}$

Structural provisions of the Constitution and separation of powers principles allocate the law-speaking power among legislators, courts, and executive officials. Congress may enact legislation, provided it follows Article I procedures. ${ }^{9}$ However, courts or executive agencies generally must apply the statute to particular disputes. The prohibition on legislative vetoes bars Congress from case-by-case application of a statute unless it satisfies the demanding constitutional process for passing new legislation. ${ }^{10}$ At the same time, the authority of judicial and executive officials to speak the law in resolving statutory

legislatures, must wait for appropriate cases to come before them and may only react to the issues presented in them.").

5 See Keene Corp. v. United States, 508 U.S. 200, 217 (1993) (dismissing petitioner's "policy arguments" as directed to "the wrong forum"); Marbury, 5 U.S. (1 Cranch) at 165 ("If some [executive] acts be examinable, and others not, there must be some rule of law to guide the court in the exercise of its jurisdiction.").

6 See Benjamin N. Cardozo, The Nature of the Judicial Process 141 (1921) ("The judge, even when he is free, is still not wholly free. He is not to innovate at pleasure. He is not a knight-errant, roaming at will in pursuit of his own ideal of beauty or of goodness."); Adam Liptak, At 89, Stevens Contemplates the Law, and How to Leave It, N.Y. Times, Apr. 4, 2010, at N4 ("Asked if he would have answered the question presented in [Kelo] differently had he instead been a legislator, Justice Stevens said probably yes. 'One of the nice things about this job is that you don't have to make those decisions,' he added. 'Very often you think, in this particular spot I don't have to be deciding the really hard case about what should be done.'”).

7 See U.S. Const. art. I, $\$ 7$ (describing the procedure for legislature to enact "a Law").

8 See 5 U.S.C. $\$ \S 553-554$ (2006) (outlining procedures for administrative rule making and adjudication).

$9 \quad$ See supra note 7.

10 See INS v. Chadha, 462 U.S. 919, 951-59 (1983) (holding that congressional action to determine individual's immigration status constituted legislative action requiring bicameralism and presentment); see also U.S. ConsT. art. I, § 9, cl. 3 (prohibiting a "Bill of Attainder"); United States v. Lovett, 328 U.S. 303, 315 (1946) ("A bill of attainder is a legislative act which inflicts punishment without a judicial trial.” (quoting Cummings v. Missouri, 71 U.S. (4 Wall.) 277, 323 (1866))). 
disputes can be superseded if Congress amends the underlying statute. ${ }^{11}$

Even in the unique context of constitutional law, care must be exercised to discern the sometimes subtle boundaries between legitimate law speaking by judges and other governmental actors. The "political question" doctrine, for instance, recognizes that some constitutional questions lie outside the judicial province, falling within the domain of the political branches. ${ }^{12}$ More controversially, "departmentalists" would accord some level of autonomy in constitutional interpretation to executive and legislative officials, even on issues previously addressed by the courts. ${ }^{13}$

This Article considers the law of precedent, including the doctrine of stare decisis, the distinction between holding and dictum, and associated principles governing the extent to which judicial resolution of a legal issue binds later courts. The analysis begins with an observation: rules of precedent serve as a mechanism for allocating the power to proclaim the law. Here the concern is not distribution of power among branches of the federal government. Rather, the law of precedent allocates power among courts of the past, present, and future. Stare decisis and subsidiary principles regulate the extent to which judges can explicate legal rules in a way that resolves not only the case before the court, but also later cases involving litigants and facts as yet unknown. ${ }^{14}$ The law of precedent, then, involves a transtemporal application of separation of powers principles, allocating power among judges serving at different points in time. ${ }^{15}$

11 See Bradley v. Sch. Bd. of Richmond, 416 U.S. 696, 711 (1974) (stating that the court generally must apply legal provisions effective at time of decision).

12 See Nixon v. United States, 506 U.S. 224, 240 (1993) (White, J., concurring in the judgment) (noting that political question doctrine concerns "whether the Constitution has given one of the political branches final responsibility for interpreting the scope and nature of" some governmental power).

13 See, e.g., Steven G. Calabresi, Caesarism, Departmentalism, and Professor Paulsen, 83 Minn. L. REv. 1421, 1421 (1999) (“[T] he text, structure, and history of our Constitution do not give the power to interpret or enforce that document to any one branch of our national government, including the federal courts.").

14 See Frederick Schauer, Giving Reasons, 47 Stan. L. Rev. 633, 654 (1995) ("Precedential constraint permits courts to influence outcomes in future cases that they may now only dimly perceive.”).

15 The law of precedent is not the only context in which separation of powers principles impact the temporal reach of those who control a branch of government. For instance, while legislative initiatives may limit options available to successors, establishing financial or legal obligations that future legislatures will be required to respect, it has traditionally been understood that "one legislature may not bind the legislative authority of its successors." United States v. Winstar Corp., 518 U.S. 839, 872 (1996) (plurality opinion); see, e.g., John O. McGinnis \& Michael B. Rappaport, 
The rule of stare decisis treats precedent as a constraint on successor judges. ${ }^{16}$ A later judge does not write on a blank slate, but must harmonize her decisions with the work of those who previously held either the same office or a superior office in the judicial hierarchy. ${ }^{17}$ From this feature of precedential reasoning flows the familiar list of values served by stare decisis, such as promoting the rule of law and protecting reliance. ${ }^{18}$ When respected, rules of precedent advance stability in the law, reducing the potential for arbitrary or unpredictable action by later judges. ${ }^{19}$

Without minimizing these benefits of presumptive adherence to precedent, this Article emphasizes a significant countervailing theme, one clearly present in the case law, but seldom highlighted in the academic literature. Just as the law of precedent gives earlier judges a check on the power of those who come behind, the doctrine sometimes allows later judges to minimize the precedential effect of earlier decisions, providing a counterbalancing check on their predecessors. ${ }^{20}$ The law of precedent, as applied by the United States Supreme Court, empowers sitting judges to police overreaching in previous opinions and to diminish the impact of rulings issued in the absence of time-honored decisionmaking practices. This power conferred on later judges serves a disciplinary function, encouraging precedent-set-

Supermajority Rules and the Judicial Confirmation Process, 26 CARdozo L. Rev. 543, 570 (2005) ("If a previous majority imposed a supermajority confirmation rule by legislative rule, the subsequent majority could repeal the rule by a majority.").

16 See James Boyd White, What's an Opinion For?, 62 U. ChI. L. Rev. 1363, 1367 (1995) (stating that law involves "the invocation of the authority of prior texts to shape and constrain what may be done in the present"); Caleb Nelson, Stare Decisis and Demonstrably Erroneous Precedents, 87 VA. L. REv. 1, 8 (2001) ("The doctrine of stare decisis would indeed be no doctrine at all if courts were free to overrule a past decision simply because they would have reached a different decision as an original matter.").

17 See David A. Strauss, Why Conservatives Shouldn't Be Originalists, 31 Harv. J.L. \& Pub. Pol'y 969, 973 (2008) (stating that precedent sharply limits options available to judges).

18 See Stephen Breyer, Making Our Democracy Work 151 (2010) (overturning a case "can create uncertainty and undermine the reliance that bench, bar, and public have invested in the earlier decision"); Randy J. Kozel, Stare Decisis as Judicial Doctrine, 67 WASH. \& LeE L. REv. 411, 454 (2010) (protecting "reliance interests" through stare decisis "has critical importance to the rule of law"); Lauren Vicki Stark, Note, The Unworkable Unworkability Test, 80 N.Y.U. L. Rev. 1665, 1669 (2005) (relying on precedent supports stability and preserves legitimacy by fostering perception that "decisions are governed by the rule of law and not by the vagaries of the political process").

19 See Stark, supra note 18, at 1669.

20 If earlier judges establish the garden of precedent, later judges tend it, nurturing some plants, pruning others, and tearing some plants out by the roots. 
ting courts to remain within the proper scope of their authority and to employ processes calculated to produce thoughtful and defensible opinions.

As we develop this thesis, it will help to have a working understanding of what we mean by the law of precedent. The relevant doctrine centers on the rule of stare decisis, the presumption that a legal conclusion in an earlier opinion continues to govern later cases in the same or inferior courts. ${ }^{21}$ Stare decisis has not been understood as "an inexorable command" or a "mechanical formula," but rather as "a principle of policy." 22 Subsidiary principles implement and qualify the stare decisis presumption, offering guidance regarding when and to what extent a prior ruling merits precedential effect. These subsidiary principles often seem characterized less by bright lines than by consideration of multiple relevant factors. ${ }^{23}$

Since the rule of stare decisis attaches only to a court's previous holdings, the distinction between holding and dictum lies at the heart of the law of precedent. ${ }^{24}$ In the quest to honor prior holdings, ambiguities can arise regarding the scope of an earlier ruling. ${ }^{25}$ Judges often possess a degree of leeway in determining how narrowly or broadly a previous opinion should be read. ${ }^{26}$ Circumstances may also influence the precedential weight accorded a prior holding. ${ }^{27}$ The strength of the presumption that an earlier legal conclusion should be

21 See Square D Co. v. Niagara Frontier Tariff Bureau, Inc., 476 U.S. 409, 424 (1986) (describing stare decisis as a "strong presumption" in statutory cases); Kurt T. Lash, Originalism, Popular Sovereignty, and Reverse Stare Decisis, 93 VA. L. Rev. 1437, 1442 (2007) (" $[\mathrm{S}]$ tandard theories of stare decisis grant precedent at least presumptive validity ....").

22 Lawrence v. Texas, 539 U.S. 558, 577 (2003) (quoting Payne v. Tennessee, 501 U.S. 808, 828 (1991)).

23 See, e.g., Planned Parenthood of Se. Pa. v. Casey, 505 U.S. 833, 854-55 (1992) (plurality opinion) ("[W]hen this Court reexamines a prior holding, its judgment is customarily informed by a series of prudential and pragmatic considerations designed to test the consistency of overruling a prior decision with the ideal of the rule of law, and to gauge the respective costs of reaffirming and overruling a prior case."); BREYER, supra note 18, at 151 (stating "[t] he Court has referred to several factors that help answer the question" when to overturn an earlier case).

24 See Michael Abramowicz \& Maxwell Stearns, Defining Dicta, 57 Stan. L. Rev. 953, 953 (2005) (“ $[\mathrm{S}]$ tare decisis applies only to holdings of announced precedents ....").

25 See, e.g., infra notes 141-55 and accompanying text.

26 See CARdozo, supra note 6, at 49 ("Sometimes the extension of a precedent goes to the limit of its logic. Sometimes it does not go so far. Sometimes by a process of analogy it is carried even farther. That is a tool which no system of jurisprudence has been able to discard.").

27 See, e.g., infra notes 170-79 and accompanying text. 
followed in later litigation can vary with the conditions under which it was announced.

This Article contends that the subsidiary principles implementing the rule of stare decisis often empower later judges to counter overreaching and less-than-careful decisionmaking by earlier courts. Applying the distinction between holding and dictum, a court can limit the scope of an opinion in which prior judges ambitiously addressed issues unnecessary for resolution of the earlier case. ${ }^{28}$ Likewise, the Supreme Court has used the law of precedent as a means to review the decisionmaking process associated with a prior opinion. When the Court has issued a ruling based on substandard briefing or truncated deliberations, or when it has failed to adequately explain the grounds for an opinion, later Justices have felt free to deny or minimize the precedential effect of the earlier decision. ${ }^{29}$ The full weight of stare decisis attaches only when the precedent-setting court sticks to the task of resolving the case before it, on the basis of plenary briefing and argument, resulting in a reasoned opinion that cogently defends the court's conclusions on the issues addressed.

Just as the general rule of stare decisis allocates power to speak the law, the authority of later judges to ignore dicta and to evaluate the quality of predecessors' decisionmaking processes effectively allocates law-speaking power over time, checking the influence of the precedent-setting court. Authorizing later courts to discount dicta creates an incentive for judicial restraint and disables ambitious judges from imposing their will in hypothetically-imagined future cases. Allowing later courts to disregard or narrowly construe decisions that were poorly briefed or inadequately explained promotes careful and thoughtful decisionmaking. Thus, the pursuit of stability inherent in the doctrine of stare decisis is qualified by countervailing goals, such as encouraging judicial self-restraint and promoting thorough, well informed consideration of legal issues.

This Article will describe and defend the law of precedent's backward-looking limitations on stare decisis and consider possible implications for several issues likely to come before the Supreme Court in future litigation. Part I considers three widely accepted expectations regarding the role and operation of courts in our legal system. First, we establish courts to resolve disputes about the application of law to particular cases. ${ }^{30}$ Second, in the course of resolving litigation, we expect courts to conduct an adequate investigation of the relevant

28 See infra notes 131-59 and accompanying text.

29 See infra notes 160-246 and accompanying text.

30 See infra notes 49-82 and accompanying text. 
facts and applicable law before reaching a conclusion, a function facilitated in appellate courts through the process of briefing, argument, and deliberation. ${ }^{31}$ Third, we ask judges, particularly at the appellate level, to memorialize their conclusions in the form of a reasoned opinion explaining the outcome they reach. ${ }^{32}$

Part II shows how the Supreme Court has employed the law of precedent to enforce these expectations regarding the role and operation of courts. The Justices have felt free to ignore legal conclusions in a prior opinion that can be fairly characterized as dicta, meaning that the Court reached beyond its role of resolving the dispute brought to it by the parties and opined on questions unnecessary to the outcome. ${ }^{33}$ When the Court has resolved an issue without adequate briefing and argument, or with minimal deliberation, later Justices have sometimes narrowly construed the resulting holding or afforded it diminished precedential weight. ${ }^{34}$ Likewise, the Court has considered the absence or inadequacy of an opinion as a factor affecting both the scope and weight of a prior ruling. ${ }^{35}$

Part III considers the potential application of these principles to particular precedents addressing issues likely to come before the Supreme Court again. Part III.A focuses on Baker v. Nelson, ${ }^{36}$ a summary disposition in which the Supreme Court dismissed "for want of [a] substantial federal question" claims that the traditional definition of marriage violates federal constitutional rights of same-sex couples. Though Baker represented a decision on the merits of the constitutional claims asserted, and though the parties provided helpful (if truncated) briefing on the issues in dispute, the lack of extended deliberation and the absence of a written opinion would make it unwise for the Supreme Court to rely on Baker as a definitive resolution of these issues in future proceedings. Questions of this gravity should be resolved through an opinion on the merits following plenary briefing and full deliberation. Indeed, I would recommend abandonment of the Court's case law attributing binding precedential effect to such summary dispositions without opinion, since they seem more akin to a denial of certiorari than a decision on the merits of the claims presented. ${ }^{37}$

31 See infra notes 83-114 and accompanying text.

32 See infra notes 115-25 and accompanying text.

33 See infra notes 131-59 and accompanying text.

34 See infra notes 160-90 and accompanying text.

35 See infra notes 191-246 and accompanying text.

36409 U.S. 810 (1972).

37 See infra notes 247-64 and accompanying text. 
Part III.B considers the liability of government officials occupying supervisory roles based on constitutional violations committed by their subordinates, an issue addressed by the Supreme Court in Ashcroft $v$. Iqbal. ${ }^{38}$ Since Iqbal involved federal officials sued under the federal common law principles of Bivens v. Six Unknown Named Agents of Federal Bureau of Narcotics, ${ }^{39}$ at the very least, Iqbal's discussion of supervisory liability should be treated as nonbinding dictum in cases involving statutory claims against state officials under 42 U.S.C. $\S 1983$. More broadly, the Iqbal dissent made a reasonable argument that the majority's discussion of supervisory liability constituted dictum even as to the federal officials at bar, since the Court's analysis of the pleadings would seem to render irrelevant its understanding of the standards for supervisory liability. In any event, to the extent one thinks Iqbal included a holding on the liability of supervisory federal officials, the Court could reasonably construe that holding narrowly in future litigation in light of the minimal briefing provided to the Iqbal Court on that issue. ${ }^{40}$

Part III.C considers the rule that the right to abortion continues until a fetus is viable, in other words, capable of surviving (with medical assistance) outside the womb. Under the principles discussed in Part II, a strong argument can be made that the Supreme Court should not accord binding precedential effect to the viability rule. The Supreme Court first announced the viability rule in Roe v. Wade, ${ }^{41}$ reaffirming the rule in somewhat altered form in Planned Parenthood of Southeastern Pennsylvania v. Casey. ${ }^{42}$ Since Roe concerned abortion regulations applicable from the outset of pregnancy, the viability rule constituted dictum in the context of the Court's opinion, a point confirmed by the internal deliberations about the case revealed in documents from the files of retired Justices. The reaffirmation of the viability rule in Casey constituted dictum as well, for much the same reason. Moreover, even if the viability rule had represented a holding in Roe or Casey, it would be entitled to diminished precedential weight since the Court in neither case enjoyed the benefit of plenary briefing or argument regarding the duration of abortion rights. Finally, neither case offered a reasoned explanation for how the viability rule can be derived from the Constitution. Given that neither Roe's adoption nor Casey's reaffirmation of the viability rule represented a hold-

38556 U.S. $662(2009)$.
39403 U.S. $388(1971)$.
$40 \quad$ See infra notes $265-310$ and accompanying text.
$41 \quad 410$ U.S. $113(1973)$.
$42 \quad 505$ U.S. $833(1992)$.


ing of the Court, and that the Court has never squarely addressed the issue on the basis of plenary briefing and argument, the Court should not feel bound by the viability rule should the question of the duration of abortion rights arise in future litigation. ${ }^{43}$

\section{The Parameters and Process of Judicial Decisionmaking}

Our occasional disagreements over the proper role of courts ${ }^{44}$ should not obscure the remarkably broad consensus concerning the function we ask courts to perform in our legal system, the decisionmaking processes we want them to employ, and the manner in which we expect them to memorialize their decisions. First, we ask courts to resolve disputes among interested parties about the application of law to particular circumstances. Courts generally may not issue legal opinions on their own initiative, but must instead settle disagreements brought to them by others. ${ }^{45}$ Second, we expect courts to follow established procedures for discovering the facts and investigating the law relevant to a particular case. At the judicial system's appellate levels, the anticipated procedures typically include adversarial briefing, often followed by oral argument, and collaborative deliberation by a multi-member panel. ${ }^{46}$ Third, especially at the appellate level, we ask courts to explain their decisions in reasoned opinions that justify the outcome through analysis of the relevant facts and applicable law. ${ }^{47}$ We frown on ipse dixit opinions that announce a conclusion without offering an adequate legal rationale. ${ }^{48}$ Let us consider in turn each of these three widely shared expectations for judicial decisionmaking.

\section{A. Courts as Forums for Resolving Disputes}

We establish courts so that parties who disagree about the application of law in particular circumstances can ask judicial officers to

43 See infra notes 311-48 and accompanying text.

44 Compare, e.g., Antonin Scalia, A Matter of Interpretation (1997) (defending textualist theory of constitutional interpretation designed to constrain judges), with Goodwin Liu eT AL., Keeping Faith with the Constitution (2010) (defending theory of fidelity in constitutional interpretation in which judges adapt constitutional text and principles in light of changed social conditions).

45 See infra notes 49-82 and accompanying text.

46 See infra notes 83-114 and accompanying text.

47 See Schauer, supra note 14, at 638 (citing the practice of giving reasons for decisions "[c]ommonly associated with appellate argument and appellate opinions").

48 See id. at 634 ("To characterize a conclusion as an ipse dixit-a bare assertion unsupported by reasons-is no compliment.”); infra notes 115-25 and accompanying text. 
resolve their dispute. ${ }^{49}$ With respect to federal courts, the Constitution assigns judges this dispute-resolution function by granting jurisdiction over certain "cases" and "controversies." 50 The "case or controversy" limitation has been implemented through the requirement of adverse parties, ${ }^{51}$ the rules of standing, ${ }^{52}$ and the prohibition on advisory opinions. ${ }^{53}$

The case-specific nature of judicial decisionmaking distinguishes the judicial power to "say what the law is" from the more general rulemaking power of a legislative body. ${ }^{54}$ Courts may not speak the law until litigants request resolution of a dispute arising from a particular set of facts. ${ }^{55}$ Courts as a general proposition endeavor to resolve legal disputes based on pre-existing sources of law, rather than simply imposing the judges' preferred outcomes. ${ }^{56}$ By contrast, the power of a legislature to speak the law is typically much broader than that of a court. A legislature may set forth a rule of law on its own initiative, even if no person requested the measure or identified concrete circumstances to which it would apply. ${ }^{57}$ Legislators are not limited to addressing one set of circumstances, but may craft a comprehensive

49 See United States v. Raines, 362 U.S. 17, 20 (1960) (holding that courts have "power and duty ... to decide cases and controversies properly before them").

50 See U.S. Const. art. III, § 2, cl. 1.

51 See Aetna Life Ins. Co. v. Haworth, 300 U.S. 227, 240-41 (1937) (requiring that the controversy touch "the legal relations of parties having adverse legal interests").

52 See DaimlerChrysler Corp. v. Cuno, 547 U.S. 332, 352 (2006) ("[A] plaintiff must demonstrate standing for each claim he seeks to press.”).

53 See United Pub. Workers of Am. (C.I.O.) v. Mitchell, 330 U.S. 75, 89 (1947) (holding that Article III courts do not render advisory opinions).

54 Chief Justice Marshall made clear in Marbury that he had in mind the judiciary's power to "say what the law is" in this case-specific context. See Marbury v. Madison, 5 U.S. (1 Cranch) 137, 177 (1803) ("Those who apply the rule to particular cases, must of necessity expound and interpret that rule.”).

55 See Robert J. Pushaw, Jr., Creating Legal Rights for Suspected Terrorists: Is the Court Being Courageous or Politically Pragmatic?, 84 Notre Dame L. Rev. 1975, 1985 n.42 (2009) (" $[\mathrm{C}]$ ourts must wait until parties commence an action and the litigation process has been completed before they can render a judgment applying the law to the facts.").

56 See Brian Z. Tamanaha, The Distorting Slant in Quantitative Studies of Judging, 50 B.C. L. Rev. 685, 688-89 (2009) ("[J]udges are realists who acknowledge that, in some cases, they make law and are guided by their personal experience and values, but believe that nevertheless, personal views play little if any role in judicial decisionmaking the vast majority of the time.").

57 See Ferguson v. Skrupa, 372 U.S. 726, 729 (1963) (“[A] state legislature can do whatever it sees fit to do unless it is restrained by some express prohibition in the Constitution of the United States or of the State ..." (quoting Tyson \& Brother United Theatre Ticket Offices, Inc. v. Banton, 273 U.S. 418, 446 (1927) (Holmes, J., dissenting))). 
\begin{tabular}{lllll}
\hline |jciprod01 $\backslash$ productnWWNDL187-4WDL402.txt & unknown & Seq: 11 & 29-MAY-12 & 12:28 \\
\hline
\end{tabular}

$2012]$

TRANSTEMPORAL SEPARATION OF POWERS

1415

legal regime anticipating a range of factual variations. ${ }^{58}$ A legislature may adopt rules based on the legislators' values, without drawing on any pre-existing source apart from the legislative power. ${ }^{59}$

In a system premised on popular sovereignty, the distinction between the law-speaking authority of legislatures and courts can be traced to considerations of legitimacy. " $[\mathrm{I}] \mathrm{n}$ a democratic society legislatures, not courts, are constituted to respond to the will and consequently the moral values of the people." 60 This is particularly true in the federal system, where judges assume office through appointment, rather than election, and enjoy constitutional protection against political accountability. ${ }^{61}$ Insulation from the political process can be an advantage when one seeks principled enforcement of legal and constitutional norms. ${ }^{62}$ It can be a disadvantage, however, when establishing broadly applicable rules, at least if one values the democratic control our political system assumes. ${ }^{63}$

The broader law-speaking authority of legislative bodies can also be justified in terms of institutional competence. ${ }^{64}$ A legislature is better positioned than a court to make far-reaching, widely applicable

58 See Or. Waste Sys., Inc. v. Dep't of Envtl. Quality, 511 U.S. 93, 110-11 (1994) (Rehnquist, C.J., dissenting) (“[A] State may enact a comprehensive regulatory system to address an environmental problem or a threat to natural resources within the confines of the Commerce Clause.”).

59 See Ofer Raban, The Supreme Court's Endorsement of a Politicized Judiciary: A Philosophical Critique, 8 J.L. Soc'y 114, 131 (2007) ("Legislators who legislate decide what, in their view, is the best course of action regarding a particular matter. Judges do not decide cases that way.").

60 Gregg v. Georgia, 428 U.S. 153, 175 (1976) (plurality opinion) (alteration in original) (quoting Furman v. Georgia, 408 U.S. 238, 383 (1972) (Burger, C.J., dissenting)).

61 See U.S. Const. art. II, § 2; id. art. III, § 1.

62 See David E. Pozen, The Irony of Judicial Elections, 108 Colum. L. Rev. 265, 272 (2008) (stating that judicial independence is beneficial "to uphold the rule of law, to check the excesses of the legislature and the executive, and to protect constitutional rights and deep-seated values against majority encroachments").

63 See Helen Hershkoff, State Courts and the "Passive Virtues": Rethinking the Judicial Function, 114 HARV. L. Rev. 1833, 1886 (2001) ("That federal judges are unelected, and federal courts presumed undemocratic, figures prominently as a justification for Article III restraint.”).

64 See Pierre N. Leval, Judging Under the Constitution: Dicta About Dicta, 81 N.Y.U. L. REv. 1249, 1260-61 (2006) ("The ideal lawmaking body would be designed to undertake a broad, integrated study of the area requiring attention. It would issue public notices so that affected persons could make submissions and participate in hearings. It would seek advice from experts. It would employ a staff to make a detailed, independent study. It would deliberate and wait as long as it considered useful before promulgating a new rule."). 
policy judgments. ${ }^{65}$ Its many members come from a variety of backgrounds and bring to their legislative deliberations a large pool of collective experience. ${ }^{66}$ A legislative body possesses the resources to conduct an extensive inquiry into the need for and consequences of particular legal changes. ${ }^{67}$ It can consider the distinct interests of all who might be impacted by a measure, including those who lack the means to hire an advocate or to speak for themselves. A legislature can also take the time it needs, studying an issue for years or even decades before it acts. ${ }^{68}$

Courts are generally in a position inferior to legislative bodies when it comes to making broadly applicable legal pronouncements. ${ }^{69}$ A court is typically a much smaller institution than a legislature and commands fewer resources. ${ }^{70}$ Judges may come from a less diverse range of socioeconomic backgrounds than legislators and typically share the advantages, but also the homogenization, that attends law

65 See Josh Benson, The Past Does Not Repeat Itself, But It Rhymes: The Second Coming of the Liberal Anti-Court Movement, 33 LAw \& Soc. InQuiry 1071, 1081 (2008) (describing Cass Sunstein's view: “Unlike a legislature, which can correct mistakes and draw on expert information, the Court lacks serious policy expertise. This means not only that sweeping rulings are likely to be wrong, but they acquire precedential value that makes them difficult to correct.").

66 See generally Jennifer E. Manning, Cong. Research Serv., Membership of the 111th Congress: A Profile (2010) (describing diverse educational backgrounds, occupations, religious affiliations, gender, ethnicity, and other characteristics of members of Congress); Adrian Vermeule, Living It Up, The New Republic (Aug. 2, 2009, 12:00 AM), http://www.tnr.com/book/review/living-it?page=0,0 (noting legislature includes "hundreds of representatives with diverse professional backgrounds and perspectives").

67 See Diamond v. Chakrabarty, 447 U.S. 303, 317 (1980) ("The choice we are urged to make is a matter of high policy for resolution within the legislative process after the kind of investigation, examination, and study that legislative bodies can provide and courts cannot."); Benson, supra note 65, at 1081 (noting that the legislature can "draw on expert information").

68 See Rory K. Little, The Federal Death Penalty: History and Some Thoughts About the Department of Justice's Role, 26 Fordham Urb. L.J. 347, 385 (1999) (explaining how Congress studied issues two decades before adopting federal death penalty procedures).

69 See Woodward v. Comm'r of Soc. Sec., 760 N.E.2d 257, 272 (Mass. 2002) (suggesting that the issue of inheritance by posthumously-conceived children "cr[ies] out for lengthy, careful examination outside the adversary process, which can only address the specific circumstances of each controversy that presents itself"); Leval, supra note 64, at 1260 (explaining that due to structure and manner of operation, courts are "poorly equipped to promulgate law").

70 See United States v. Richardson, 418 U.S. 166, 192 (1974) (Powell, J., concurring) (noting need to prevent diversion of courts' "limited resources"). 
school training. ${ }^{71}$ A court must confine its deliberations to a record compiled by the parties, ${ }^{72}$ who often have motives to offer selective portrayals of the relevant facts. ${ }^{73}$ The court may possess little insight into how its ruling might affect those not involved in the litigation, ${ }^{74}$ and it generally resolves cases under considerable time pressure. ${ }^{75}$

Limiting court jurisdiction to the task of resolving discrete legal disputes gives rise to the distinction between holding and dictum. ${ }^{76} \mathrm{~A}$ court's holding carries precedential authority because, by definition, it encompasses those parts of an opinion necessary to the judges' assigned task of resolving the case. ${ }^{77}$ When a court articulates the holding of a case, it carries out the function it is authorized to perform-settling the dispute between the parties. Conversely, statements in dicta lack authority because they are not required for the court to perform its role of resolving the pending legal dispute. In offering dicta, the judge goes beyond the authorized judicial function. ${ }^{78}$

71 See Sherrilyn A. Ifill, Judicial Diversity, 13 Green Bag 2d 45, 46-49 (2009) (discussing lack of diversity with respect to gender, race, and professional backgrounds); $i d$. at 54 ("All federal judges are lawyers-distinguished ones."); Vermeule, supra note 66 (characterizing a court as a "committee of aging lawyers on the bench, with limited information and life experience and no philosophical or penological training").

72 See Pharm. Research \& Mfrs. of Am. v. Walsh, 538 U.S. 644, 687-88 (2002) (O'Connor, J., concurring in part and dissenting in part) (stating that appellate review of injunction is confined to record before district court); BREYER, supra note 18, at 114 ("[Courts] cannot look for information beyond [the] record."); Leval, supra note 64, at 1261 ("Usually, the only input the court receives is from the litigants. The court is barred from researching the facts privately on its own." (footnote omitted)).

73 See Gerald Lebovits et al., Ethical Judicial Opinion Writing, 21 GEo. J. Legal EthICS 237, 287 (2008) (discussing how litigants may "shade facts" due to interest in litigation).

74 See Benson, supra note 65, at 1081 (noting that a court "lacks serious policy expertise").

75 See Breyer, supra note 18, at 114 ("Judges have little time to spend on any one case . . . ."); Margaret Meriwether Cordray \& Richard Cordray, The Calendar of the Justices: How the Supreme Court's Timing Affects Its Decisionmaking, 36 ARIz. ST. L.J. 183, 213 (2004) (explaining how the Supreme Court has "barely two months" to issue decisions in cases argued in April); Randy J. Holland, Delaware's Business Courts: Litigation Leadership, 34 J. CoRP. L. 771, 777-78 (2009) (discussing the rapid decisionmaking in Delaware appellate courts).

76 See CARdozo, supra note 6, at 29 ("[T] he thing adjudged comes to us oftentimes swathed in obscuring dicta, which must be stripped off and cast aside.”).

77 See Leval, supra note 64, at 1260 ("Courts make law only as a consequence of the performance of their constitutional duty to decide cases. They have no constitutional authority to establish law otherwise.").

78 See id. ("[M]aking law through dictum . . . . is beyond our authority."). 
From a more functional perspective, the Supreme Court has argued that a court's dicta are less reliable than its holdings. A court devotes its attention principally to the case before it, rather than cases that might hypothetically arise in the future. Chief Justice Marshall famously explained the reasons for denying precedential effect to dicta:

It is a maxim not to be disregarded, that general expressions, in every opinion, are to be taken in connection with the case in which those expressions are used. If they go beyond the case, they may be respected, but ought not to control the judgment in a subsequent suit when the very point is presented for decision. The reason of this maxim is obvious. The question actually before the Court is investigated with care, and considered in its full extent. Other principles which may serve to illustrate it are considered in their relation to the case decided, but their possible bearing on all other cases is seldom completely investigated. ${ }^{79}$

Thus, concerns about the legitimacy of a court's unnecessary resolution of legal issues interrelate with concerns about institutional competence and the quality of the court's decisionmaking process. ${ }^{80}$ The circumstances in which a court is authorized to speak the law are also the circumstances in which it can be expected to do so most reliably and with the greatest forethought.

This does not mean a court necessarily acts improperly when it includes dicta in an opinion. A court probably should consider how the principles underlying its ruling might apply in light of predictable variations in the facts. Offering guidance for later cases, or highlighting potential distinguishing factors, can be useful for future parties and courts. ${ }^{81}$ But the inclusion of dicta in an opinion can also be a form of judicial overreaching-an attempt to address unlitigated

79 Cohens v. Virginia, 19 U.S. (6 Wheat) 264, 399-400 (1821).

80 See CARDozo, supra note 6, at 29-30 ("I own that it is a good deal of a mystery to me how judges, of all persons in the world, should put their faith in dicta. A brief experience on the bench was enough to reveal to me all sorts of cracks and crevices and loopholes in my own opinions when picked up a few months after delivery, and reread with due contrition."); Leval, supra note 64, at 1255 ("An important aspect of my point is that courts are more likely to exercise flawed, ill-considered judgment, more likely to overlook salutary cautions and contraindications, more likely to pronounce flawed rules, when uttering dicta than when deciding their cases. The practices I discuss impair the quality and reliability of our performance.”).

81 See Leval, supra note 64, at 1253 ("[D]icta often serve extremely valuable purposes. They can help clarify a complicated subject. They can assist future courts to reach sensible, well-reasoned results. They can help lawyers and society to predict the future course of the court's rulings. They can guide future courts to adopt fair and efficient procedures."). 
\begin{tabular}{lllll}
\hline |yciprod01 $\backslash$ productnLNWDL187-4WNDL402.txt & unknown & Seq: 15 & 29-MAY-12 & 12:28 \\
\hline
\end{tabular}

2012]

TRANSTEMPORAL SEPARATION OF POWERS

1419

issues and resolve future disputes beyond the precedent-setting court's jurisdiction. ${ }^{82}$

\section{B. Briefing, Argument, and Deliberation}

If the legal system's only goal were resolution of disputes, we could replace judges with coin flips and games of chance (at much lower cost). ${ }^{83}$ We invest substantial resources in our legal system because we believe law can play a socially beneficial role in influencing behavior. ${ }^{84}$ That belief rests on an assumption that law possesses some degree of determinacy or predictability, arising from the interaction of language, reason, and shared interpretive practices. ${ }^{85} \mathrm{We}$ assume that the plausible outcomes for a particular legal inquiryoutcomes consistent with the language of the law, understood in light of the conventions of legal interpretation and the dictates of reasonfall within a sufficiently narrow range to permit suitably determinate guidance to further the goals that motivated lawmakers. The need for relatively predictable legal decisions means that some judicial opinions will be better than others; some will be more accurate (or, indeed, truthful) in describing the relevant facts, or more faithful in applying the relevant legal directives in light of our shared interpretive norms. ${ }^{86}$

In preparing to write a factually accurate opinion that faithfully applies the law, a judge must undertake an educational process. At a minimum, the educational process required to resolve a case involves investigation of facts relevant to the dispute, typically through compilation of a record at the trial-court level or familiarization with rele-

82 See id. at 1250 ("We judges regularly undertake to promulgate law through utterance of dictum made to look like a holding-in disguise, so to speak. When we do so, we seek to exercise a lawmaking power that we do not rightfully possess.").

83 Cf. 10 Ill. Comp. Stat. Ann. 5/23-27 (West 2010) (mandating that in case of equal votes for same office, election should be decided by lot); Huber v. Reznick, 437 N.E.2d 828, 839 (Ill. App. Ct. 1982) (ruling that an electoral contest was properly resolved by coin flip).

84 See Harry Surden, The Variable Determinacy Thesis, 12 Colum. Sci. \& Tech. L. REv. 1, 34 (2011) (suggesting that the law seeks "to influence human behavior in desirable ways").

85 See Cass R. Sunstein, Interpreting Statutes in the Regulatory State, 103 Harv. L. Rev. 405, 441-42 (1989) (asserting that there is agreement on background norms of statutory interpretation making judicial interpretations predictable).

86 See Suzanna Sherry, The Four Pillars of Constitutional Doctrine, 32 Cardozo L. REv. 969, 971-74 (2011) (discussing legal reasoning and candor as grounds for evaluating judicial opinions). 
vant portions of the record in an appellate court. ${ }^{87}$ In many cases, judges will also need to broaden their familiarity with applicable law through review of pertinent legal directives and precedent interpreting those directives. ${ }^{88}$

Appellate judges, such as the Justices of the United States Supreme Court, could theoretically conduct the factual and legal investigations necessary to their work without the input of the parties, perhaps after minimal guidance as to the issues in dispute. Drawing from centuries of experience, though, our courts have concluded that adversarial briefing and oral argument by lawyers for the parties enhances the educational process necessary for appellate decisionmaking. ${ }^{89}$ The Supreme Court places such reliance on the assistance of attorneys that the Justices often refuse to adjudicate issues-even issues undeniably relevant to a given dispute-in the absence of adequate briefing and argument. ${ }^{90}$ Just as frequently, concurring and dis-

87 See Fed. Judicial Ctr., Judicial Writing Manual 11 (1991) ("When an opinion turns on the specifics of testimony or on what occurred in the court room, there may be no substitute for reading the relevant portions of the transcript."); Lebovits et al., supra note 73, at 287 ("Trial judges must engage in fact finding and resolve conflicts between different versions of the facts ....”).

88 See FED. Judicial CTR., supra note 87, at 9 (suggesting that before writing opinion, judge must "identify the applicable rules of law").

89 See Teague v. Lane, 489 U.S. 288, 331 (1989) (Brennan, J., dissenting) (recognizing the "aid which adequate briefing and argument lends to the determination of an important issue” (quoting Mapp v. Ohio, 367 U.S. 643, 677 (1961) (Harlan, J., dissenting))).

90 See Cooper Indus., Inc. v. Aviall Servs., Inc., 543 U.S. 157, 168-70 (2004) (refusing to resolve issue addressed by dissent where issue had not been resolved below and went "well beyond the scope of the briefing and, indeed, the question presented"); USPS. v. Gregory, 534 U.S. 1, 7 (2001) (“[E]ven if the adequacy of [agency's method of reviewing prior disciplinary actions] were before us, we lack sufficient briefing on its specific functioning in this case.”); Ky. Dep't of Cntys. v. Thompson, 490 U.S. 454, 465 n.5 (1989) (declining to consider whether consent decree could create liberty interest where issue not briefed and argued, not discussed below, and unnecessary to decision); Bowen v. Yuckert, 482 U.S. 137, 153 n.11 (1987) (noting dissent resolved issue of vagueness of regulation "[a]lthough the issue was not briefed or argued by the parties"); Aetna Life Ins. Co. v. Lavoie, 475 U.S. 813, 827 n.4 (1986) ("We have confined the opinion to the issues presented by the parties and express no view on the question discussed by the justices who write separately. . . . Because the issue of disqualification of a single member of a multimember panel arises in a variety of factual contexts, sound judicial practice wisely counsels judges to avoid unnecessary declarations on issues not presented, briefed, or argued." (citation omitted)); EEOC v. Shell Oil Co., 466 U.S. 54, 66 n.17 (1984) (explaining that the parties shared an assumption about the Title VII enforcement question, so "the issue has not been briefed," and that the Court "loathe[d] to take an analytical path unmarked by the litigants," especially in complex area of law); Connell Constr. Co. v. Plumbers \& Steamfitters Local Union No. 100, 421 U.S. 616, 637 (1975) (remanding for consider- 
senting Justices criticize the majority for taking up issues the briefs did not address or treated in a cursory fashion. ${ }^{91}$ The significance attributed to briefing and argument in both majority and nonmajority opinions demonstrates recognition that the quality of briefing affects the

ation of issue not considered below and "not briefed and argued fully in this Court"); Sherman v. United States, 356 U.S. 369, 376 (1958) (declining to address issues "without the benefit of argument by the parties"); United States v. Reading Co., 228 U.S. 158, 160 (1913) ("Upon this issue the transcript is confusing and the briefs inadequate. The court therefore deems it wise in the exercise of its judgment to decline any determination of the question upon the present record.").

91 See Kolstad v. Am. Dental Ass'n, 527 U.S. 526, 553 (1999) (Stevens, J., concurring in part and dissenting in part) ("The absence of briefing or meaningful argument by the parties makes this Court's gratuitous decision to volunteer an opinion on this nonissue particularly ill advised.”); Missouri v. Jenkins, 515 U.S. 70, 138-39, 143-48 (1995) (Souter, J., dissenting) (explaining that the court should not decide issue not clearly included in questions presented, resulting in lack of notice and inadequate briefing); R.A.V. v. City of St. Paul, Minn., 505 U.S. 377, 398 (1992) (White, J., concurring in the judgment) (" $[\mathrm{I}] \mathrm{n}$ the present case, the majority casts aside longestablished First Amendment doctrine without the benefit of briefing and adopts an untried theory."); Teague, 489 U.S. at 319-20 (Stevens, J., concurring in part and concurring in the judgment) (questioning "the propriety of making such an important change in the law without briefing or argument," but partially agreeing with plurality's resolution of retroactivity issue); $i d$. at 326 (Brennan, J., dissenting) ("Today a plurality of this Court, without benefit of briefing and oral argument, adopts a novel threshold test for federal review of state criminal convictions on habeas corpus."); Sun Oil Co. v. Wortman, 486 U.S. 717, 739 (1988) (Brennan, J., concurring in part and concurring in judgment) (criticizing majority's "offhand treatment" of issue not briefed or argued); United States v. Sharpe, 470 U.S. 675, 700-02 (1985) (Marshall, J., concurring in the judgment) (suggesting that the majority erred in addressing reasonable suspicion issue "not presented, briefed, or argued by the parties" and not fully reviewed in trial court); Mapp, 367 U.S. at 676-77 (Harlan, J., dissenting) (critiquing the "unwisdom of overruling [ Wolf v. Colorado, 338 U.S. 25 (1949)] without fulldress argument"); see also Lackawanna Cty. Dist. Att'y v. Coss, 532 U.S. 394, 410 (2001) (Breyer, J., dissenting) (arguing majority's discussion premature where a related issue was not raised and thus "the issue has not been briefed"); $c f$. Harper v. Va. Dep't of Taxation, 509 U.S. 86, 120 (1993) (O’Connor, J., dissenting) (arguing that the majority should not view prior case articulating rule as determinative on issue of retroactivity where " $[\mathrm{t}]$ he absence of briefing, argument, or even mention of the question belies any suggestion that the issue was given thoughtful consideration"); United States v. N.Y. Tel. Co., 434 U.S. 159, 184 (1977) (Stevens, J., dissenting in part) (rejecting proposition suggested in dicta in prior case, but "not briefed"). But see Jenkins, 515 U.S. at 83-86 (majority opinion) (arguing that the question was considered by courts below, fairly included in questions presented and briefed by parties); $i d$. at 103-05 (O’Connor, J., concurring) (suggesting that the question was fairly included in one of the questions presented and briefed by parties). 
quality of the Court's opinions; inadequate briefs can produce poor decisions. ${ }^{92}$

Consider some ways that briefing and argument by the parties might contribute to the quality of decisionmaking in an appellate court. At the very least, the briefing process will save time and effort for the judges. The parties can identify relevant testimony and exhibits more quickly than an appellate judge. ${ }^{93}$ The litigants can also accelerate the search for relevant legal sources, reducing the risk that the court will overlook important precedents and principles that its decision should take into account. ${ }^{94}$ The time saved by adversarial briefing can be devoted to higher-order tasks, like thinking through the implications of a particular outcome in light of the court's larger body of jurisprudence.

Our preference for adversarial briefing and argument, however, does not flow simply from the desire to preserve judicial resources. Allowing each party to present its own case may also highlight important considerations the judge might otherwise overlook. The human mind sometimes begins forming views on an issue based on relatively minimal information. Judges may reach tentative conclusions when they first hear about a case, but those conclusions will often prove untenable in light of a more complete understanding of the dispute. ${ }^{95}$ Hearing a party's position on contested issues can force a judge to question his or her assumptions about the case and take account of information undermining the judge's initial reaction.

More broadly, adversarial briefing can help to overcome "blind spots" arising from a judge's background. ${ }^{96}$ Each judge comes to a

92 The Court made this point recently when it overruled Saucier v. Katz, 533 U.S. 194 (2001), which had required judges to decide constitutional issues presented by a $\S 1983$ or Bivens plaintiff before moving on to consider the question of qualified immunity. As one reason for freeing judges to start with the issue of qualified immunity, the Court explained that where "the briefing of constitutional questions is woefully inadequate," demanding an opinion on the constitutional issue would "create a risk of bad decisionmaking." Pearson v. Callahan, 555 U.S. 223, 239 (2009).

93 See Sup. Cт. R. 26.1 (2010) (requiring submission of joint appendix including "parts of the record that the parties particularly wish to bring to the Court's attention").

94 See Sup. Cт. R. 24.1(i) (requiring parties to cite authorities relied upon).

95 See Edward Brunet, Judicial Mediation and Signaling, 3 Nev. L.J. 232, 252 (2002) (suggesting judges sometimes engage in signaling that "solicits the parties to submit additional information that might change the judge's tentative thinking," prompting "new evidence that can aid the judge in reaching a more fully informed decision").

96 See Victoria Nourse \& Gregory Shaffer, Varieties of New Legal Realism: Can a New World Order Prompt a New Legal Theory?, 95 Connell L. Rev. 61, 104-05 (2009) ("[J]udges too are people with blind spots and thus exhibit predictable cognitive failures.”); Edmund B. Spaeth, Jr., How Do Judges Decide? A Course for Non-Lawyers, 106 
case from a particular perspective shaped by the judge's experiences. ${ }^{97}$ A judge needs to see what the dispute looks like from the perspectives of the parties. ${ }^{98}$ Getting a different angle on the issues in controversy may help a judge remove the blinders created by his or her background and see more clearly the "practical ramifications" of a particular outcome for those most directly affected. ${ }^{99}$ The parties can present their positions in the strongest possible terms and give the best exposition of how their interests will be impacted by the litigation.

Adversarial briefing likewise allows for a thorough sifting of the positions advanced by the contending parties. Many arguments may appear persuasive when considered in isolation. "The first to present his case seems right, till another comes forward and questions him." 100 In adversarial litigation, each side has an incentive to highlight omissions and expose flaws in the other side's position, rounding out the court's awareness of the relevant facts and law and the strengths and weaknesses of potential legal resolutions.

For cases argued in the United States Supreme Court, the process of briefing and argument structures the dispute in the form of an extended dialogue between the parties. At the initial stage of asking the Court to take the case, there will typically be a petition for certiorari, a brief in response, and sometimes a reply brief. ${ }^{101}$ The Court's decision to grant certiorari is followed by submission of lengthier briefs on the merits, ${ }^{102}$ with each party potentially supported by multiple amici curiae. ${ }^{103}$ The parties get a final opportunity to influence

Dick. L. Rev. 773, 796 (2002) ("We are all children of our time, which means that we all have blind spots, emphatically including our judges . ...").

97 See, e.g., Ifill, supra note 71, at 55 (arguing that judges bring "accumulated knowledge" from their experiences to the resolution of cases); Liptak, supra note 6 , at 44 ("'I've confessed to many people that I think my personal experience has had an impact on what I've done,' [Justice Stevens] said. 'Time and time again, not only for myself but for other people on the court, during discussions of cases you bring up experiences that you are familiar with." ").

98 See R.A.V. v. City of St. Paul, Minn., 505 U.S. 377, 398 (1992) (White, J., concurring in the judgment) (explaining that full briefing and argument gives parties and amici "the opportunity to apprise us of the impact of a change in the law").

99 See Mapp v. Ohio, 367 U.S. 643, 676 (1961) (Harlan, J., dissenting) (critiquing majority for reaching out to resolve issue with cursory briefing and no argument; decision may have "untoward practical ramifications" for state criminal justice proceedings).

100 Proverbs 18:17 (NIV).

101 See Sup. Ct. R. 12, 15 (2010).

102 See Sup. Ct. R. 25.

103 See Sup. Ci. R. 37. 
the Court's thinking through oral presentation of their positions. ${ }^{104}$ This extensive course of briefing and argument gives each side multiple opportunities to make their strongest points and highlight weaknesses in the other side's submissions.

Public oral argument offers additional advantages that can enhance the judicial decisionmaking process, setting a point in time by which the judges will have read the briefs and developed a basic familiarity with the issues in dispute. ${ }^{105}$ The oral argument gives advocates an opportunity to respond to particular issues of concern to the decision makers. ${ }^{106}$ Oral argument also shows the public that the judges are personally engaged in considering the issues presented and have not simply left matters in the hands of their law clerks. ${ }^{107}$ Finally, in the context of the Supreme Court, many have noted that the questions asked by the Justices are often directed to one another, as much as to the parties. ${ }^{108}$ The oral argument begins the process of collaborative deliberation that will lead to a final opinion.

While briefing and argument initiate the process of judicial education, that educational process continues through private study and

104 See Sup. Ciт. R. 28.

105 See James C. Phillips \& Edward L. Carter, Source of Information or "Dog and Pony Show"?: Judicial Information Seeking During U.S. Supreme Court Oral Argument, 1963-1965 E 2004-2009, 50 Santa Clara L. Rev. 79, 90 (2010) ("Oral argument . . . is the organizing point for the entire judicial process. The judges read the briefs, do the research, and talk to their law clerks to prepare for the argument. The voting conference is held right after the oral argument-immediately after it in the court of appeals, shortly after it in the Supreme Court. And without disputing in any way the dominance of the briefing in the decisional process, it is natural, with the voting coming so closely on the heels of oral argument, that the discussion at conference is going to focus on what took place at argument." (quoting John G. Roberts, Jr., Oral Advocacy and the Re-emergence of a Supreme Court Bar, 30 J. Sup. Cт. Hist. 68, 70 (2005))).

106 See Eugene Gressman et al., Supreme Court Practice 750 (9th ed. 2007) ("[O]ften my whole notion of what a case is about crystallizes at oral argument." (quoting William J. Brennan, Jr., Harvard Law School Occasional Pamphlet No. 9, 22-23 (1967))).

107 Cf. David J. Garrow, The Brains Behind Blackmun, Legal Affairs (May/June 2005), at 27, 28 (discussing responsibility of Justices to supervise law clerks and not give them too much control over official responsibilities).

108 See Phillips \& Carter, supra note 105, at 89 ("I soon learned that . . questioning from the bench was . . . a form of lobbying for votes." (alterations in original) (quoting Phillip J. Cooper, Battles on the Bench 72 (1995))); id. ("[A] second important function of oral argument can be gleaned from the fact that it is the only time before conference discussion of the case later in the week when all of the judges are expected to sit on the bench and concentrate on one particular case. The judges' questions, although nominally directed to the attorney arguing the case, may in fact be for the benefit of their colleagues." (quoting William H. Rehnquist, The Supreme Court $244(2001)))$. 
collegial deliberation. Since the parties' presentations are driven by an agenda of prevailing in the litigation, it is important that judges have time to supplement the parties' research and engage in more neutral and dispassionate consideration of the issues in dispute. The judges need to determine whether the parties have accurately characterized the record and the case law, to consider issues the parties did not raise, and to anticipate implications of different outcomes for future disputes where the facts might differ. ${ }^{109}$

After oral argument, appellate judges typically begin an extended process of continued research and collective deliberation. The development of consensus among a group of judges on a multi-member appellate court may smooth out some of the biases and idiosyncrasies that can lead a single judge to a flawed result. ${ }^{110}$ Moreover, multiple judges may challenge one another to consider possibilities an individual judge would overlook. ${ }^{111}$ In the Supreme Court, the Justices meet soon after oral argument for a private conference that facilitates this process of personal study and collaborative deliberation. ${ }^{112}$ The Justices explain their tentative views on the proper outcome of an argued case. ${ }^{113}$ The conference results in initial opinion assignments, ${ }^{114}$ and the process of study and deliberation continues as the Justices circu-

109 See Gerald Lebovits \& Lucero Ramirez Hidalgo, Advice to Law Clerks: How to Draft Your First Judicial Opinion, 36 Westchester BAR J. 29, 30 (2009) (explaining that parties will sometimes omit issues or state them incorrectly).

110 See CARdozo, supra note 6, at 177 ("The eccentricities of judges balance one another. One judge looks at problems from the point of view of history, another from that of philosophy, another from that of social utility, one is a formalist, another a latitudinarian, one is timorous of change, another dissatisfied with the present; out of the attrition of diverse minds there is beaten something which has a constancy and uniformity and average value greater than its component elements."); Chris Scaperlanda, Approximating Due Process, 28 Rev. Litig. 983, 994 (2009) ("The dialogue among judges necessary to reach a conclusion and the presence of two votes to outweigh any personal biases or blind spots that might influence one judge's decision all suggest that a three-judge panel is more likely to be error free than a decision by a single judge.").

111 See Evan H. Caminker, Sincere and Strategic Voting Norms on Multimember Courts, 97 Mich. L. Rev. 2297, 2310 (1999) ("The process of collective deliberation can improve autonomous decisionmaking. A collegial sharing of ideas brings multiple possibilities and perspectives to each Justice's attention, and increases the likelihood that she will explore all plausible positions. Moreover, each Justice is encouraged to hone and improve her own positions in response to critical peer scrutiny and persuasion." (footnote omitted)).

112 See Gressman et AL., supra note 106, at 22.

113 See id.

114 See id. at 15 (quoting William H. Rehnquist, Sunshine in the Third Branch, 16 WASHBurn L.J. 559, 559-60 n.1 (1977)). 
late and comment on drafts of majority, concurring, and dissenting opinions.

In short, appellate courts such as the United States Supreme Court rely on briefing and argument to enhance the quality of the decisions issued by judges. Inadequate briefing and argument contribute to inadequate judicial opinions. Good briefing and argument do not guarantee good decisions, but they increase the likelihood that judges will produce thoughtful rulings, truthful about the relevant facts, faithful to the applicable law, and useful in accomplishing the goals the legal system seeks to advance.

\section{Reasoned Explanation of Judicial Decisions}

In addition to educating themselves as to the relevant facts and applicable law, we ask courts to write opinions that explain the legal analysis leading to an announced outcome. ${ }^{115}$ Just as briefing, argument, and collaborative deliberation tend to enhance the quality of judicial decisions, the process of writing opinions can improve judicial decisionmaking as well. Writing out one's legal analysis serves as a discipline that can force judges to think more carefully and systematically about the issues in dispute. ${ }^{116}$ The requirement of written justification forces a judge to move from a gut reaction to a reasoned conclusion. ${ }^{117}$ Many judges recognize this benefit of authoring opinions and will sometimes express only tentative views after oral argument because they want to see if a particular analysis "will write," in other words, if it can be persuasively developed in the form of a judicial opinion. ${ }^{118}$ The writing process forces the court to face important issues and decide whether a particular outcome can be explained in a defensible way.

When a court offers persuasive explanations for its decisions, its opinions tend to bolster the court's legitimacy in the eyes of the pub-

115 See White, supra note 16, at 1366 (explaining that judicial opinion includes "the reasons why the result was reached").

116 See Schauer, supra note 14, at 657-58 (discussing how the requirement of giving reasons for decisions can counteract problems like "bias, self-interest, insufficient reflection, or simply excess haste").

117 See Sherry, supra note 86, at 973 ("Transparency is especially vital for unelected judges in a constitutional democracy, because the visible rationality of a transparent opinion is a necessary substitute for the missing democratic accountability. It is part of what leads the public to acknowledge the legitimacy of a judicial decision.").

118 See Schauer, supra note 14, at 652 (mentioning phenomenon of judges struggling with opinion before concluding it “won't write”).

$\mathbf{R}$

R 
lic. ${ }^{119}$ This matters because the efficacy of courts in fulfilling their functions depends to a large extent on public acquiescence. Courts have only limited capacity to compel submission, so voluntary compliance by the public is critical. ${ }^{120}$ Widespread doubt about the legitimacy of the courts would profoundly impact their ability to perform their public functions.

Issuance of written opinions also provides one of the few means of holding courts accountable, ${ }^{121}$ permitting review and critique of the legal analyses judges offer in support of their decisions. ${ }^{122}$ The transparency afforded by judicial opinions allows the public to express disapproval and criticize judges who reach decisions the public considers poorly reasoned or legally indefensible. ${ }^{123}$ A written opinion can also highlight options available to political actors with means of responding to a court's decision.

Reasoned opinions explaining judicial outcomes promote the rule of law values underlying the law of precedent. ${ }^{124}$ A court's explanation of the principles applied and its analysis of how those principles interact with the relevant facts can offer guidance as to the possible application of those principles in later cases. ${ }^{125}$ In this manner, the publication of judicial opinions provides direction to lawyers, litigants, and future courts.

119 See id. at 658 (“[W] hen decisionmakers expect voluntary compliance, or when they expect respect for decisions because the decisions are right rather than because they emanate from an authoritative source, then giving reasons becomes a way to bring the subject of the decision into the enterprise.").

120 See Planned Parenthood of Se. Pa. v. Casey, 505 U.S. 833, 865 (1992) (plurality opinion).

121 See Fed. Judicial Ctr., supra note 87, at vii ("[I]n the writing lies the test of the thinking that underlies [the opinion]."); $i d$. at 1 ("[P]reparation of a written opinion imposes intellectual discipline on the author, requiring the judge to clarify his or her reasoning and assess the sufficiency of precedential support.").

122 See Lebovits et al., supra note 73, at 273 ("[Opinions] provide accountability because they are available to the public, the litigants, and higher courts to read and review.").

123 See White, supra note 16, at 1368 ("The criticism of opinions, on all these grounds-rational, political, moral-is an essential part of the activity of law. It is crucial to legal practice, for it is on the basis of such criticism that one will argue for or against the continued authority of a particular opinion or line of opinions.”).

124 See Schauer, supra note 14, at 654 (arguing for adherence to reasons in earlier opinions for "cross-temporal stability, and for intrainstitutional stability in the face of changing personnel”).

125 See White, supra note 16, at 1368 (“[T] he way the opinion is written has large consequences for the future. It deeply affects and shapes the way we think and argue and, in so doing, constitute ourselves through the law."). 


\section{The Law of Precedent as a Check on Prior Courts}

Discussions of the law of precedent often focus on the presumption against reconsidering prior decisions. ${ }^{126}$ Considerable advantages flow from presumptive adherence to earlier rulings. Following previous decisions means that like cases will be resolved in like manner, promoting "faith in the even-handed administration of justice" 127 and guarding against "prejudice or favor or even arbitrary whim or fitfulness." 128 Adherence to precedent increases the predictability of legal outcomes and protects those who rely on judicial pronouncements, promoting the rule of law. ${ }^{129}$ Stare decisis also preserves judicial resources, since "the labor of judges would be increased almost to the breaking point if every past decision could be reopened in every case." 130

When one focuses principally on the presumption against overruling prior decisions, the law of precedent clearly empowers earlier courts at the expense of those that come later. This Article, however, seeks to present a more nuanced picture of the way the law of precedent operates in practice. A complete discussion of the Supreme Court's stare decisis jurisprudence must take account of the Court's willingness to deny precedential effect to dicta and to narrowly construe prior decisions in ways that minimize their impact. Moreover, not all judicial decisions carry equal precedential weight; the Court feels more freedom to reconsider some rulings than others. A more comprehensive picture of the law of precedent shows that the Court balances values such as promoting stability and protecting reliance against countervailing values. While the law of precedent does give precedent-setting courts the capacity to bind their successors, it also equips successor judges with tools to rein in excesses and discourage suboptimal decisionmaking practices by their predecessors.

The first Part of this Article considered three expectations regarding the role and operation of courts in our legal system: (1)

126 See, e.g., Planned Parenthood of Se. Pa. v. Casey, 505 U.S. 833, 854-55 (1992) (plurality opinion); BREYER, supra note 18, at 151-56 (discussing factors influencing the decision whether to overrule a prior decision).

127 CARdozo, supra note 6, at 34 .

$128 I d$. at 112.

129 See Itel Containers Int'l Corp. v. Huddleston, 507 U.S. 60, 79 (1993) (Scalia, J., concurring in part and concurring in the judgment) (describing as "principal purposes" of stare decisis "to protect reliance interests and to foster stability in the law"); Welch v. Tex. Dep't of Highways \& Pub. Transp., 483 U.S. 468, 494 (1987) (plurality opinion) (" $[\mathrm{T}]$ he doctrine of stare decisis is of fundamental importance to the rule of law.").

130 CARDozo, supra note 6, at 149 . 
that courts should resolve disputes brought to them by others concerning the application of law to particular circumstances, (2) that courts should render decisions with the benefit of full briefing, argument, and deliberation, and (3) that courts should explain the legal analyses supporting the conclusions they reach. We will now examine the Supreme Court's application of the law of precedent to enforce these expectations. As we will see, the Court narrowly construes prior decisions, accords diminished precedential weight, or denies stare decisis effect altogether when an earlier Court purported to resolve issues not raised by the case before it, when it acted based on inadequate briefing or cursory deliberation, or when it failed to adequately explain the reasoning underlying a legal conclusion.

\section{A. Denying Binding Effect to Dicta}

The law of precedent places controlling weight on the distinction between holding and dictum. ${ }^{131}$ The only portions of an opinion entitled to binding effect under the rule of stare decisis are those necessary to resolution of the dispute pending before the precedent-setting court. Portions of an opinion that constitute dicta may be considered for their persuasive value, but need not be followed in later litigation. ${ }^{132}$

We previously noted that the distinction between holding and dictum tracks the Court's jurisdiction as an institution authorized to resolve disputes about the application of law to particular circumstances. ${ }^{133}$ Considered as a manifestation of separation of powers doctrine, the holding/dictum distinction allows later courts to remedy overreaching by their judicial predecessors. ${ }^{134}$ Dicta can of course be a legitimate tool of judicial decisionmaking, even for a minimalist court. Courts may use dicta, for instance, to illustrate the limited scope of a particular ruling and alert lawyers, judges, and legislators to factual variations that could call for application of different principles. ${ }^{135}$ But dicta can also represent an attempt by the precedent-set-

131 See supra notes 76-78 and accompanying text.

132 See Parents Involved in Cmty. Schs. v. Seattle Sch. Dist. No. 1, 551 U.S. 701, 737-38 (2007) (plurality opinion) (holding that dicta from a prior case was not binding in later one).

133 See supra Part I.A.

134 See Local 144 Nursing Home Pension Fund v. Demisay, 508 U.S. 581, 592 n.5 (1993) (declining to give effect to dicta in prior cases).

135 For instance, in striking down a statute criminalizing consensual homosexual sodomy, the majority in Lawrence $v$. Texas employed dicta to identify a number of potentially relevant facts that were not present in the case under review. The majority wrote: "The present case does not involve minors. It does not involve persons who 
ting court to reach outside the bounds of its authority in an ambitious attempt to control the outcome in future cases with different facts. The Supreme Court has recognized that dicta can "insult" the virtue of judicial restraint, and that a later court "would add injury to insult by according them precedential effect." 136 The holding/dictum distinction allows a later court to ignore an earlier opinion to the extent the first court exceeded its authority.

The distinction between holding and dictum implicates concerns about the institutional competence of courts and the importance of adversarial litigation. Parties involved in a lawsuit have little reason to provide extensive briefing and argument on issues unnecessary to the resolution of the particular case. ${ }^{137}$ Therefore, an opinion's dicta will often concern issues "not fully debated" by the parties. ${ }^{138}$ Likewise, as Chief Justice Marshall explained in Cohens $v$. Virginia, ${ }^{139}$ while " $[\mathrm{t}] \mathrm{he}$ question actually before the Court is investigated with care, and considered in its full extent," other issues are "seldom completely investigated." 140 Consequently, there is a higher risk that a court formulating dicta will possess incomplete information than a court addressing issues directly involved in the parties' dispute.

This brings us to the question of how courts should distinguish holding from dictum in interpreting an earlier opinion. Professor Michael Dorf has noted that the Supreme Court lacks a single, uniform approach to drawing the holding/dictum distinction. The Court sometimes views a prior holding narrowly, encompassing only the facts of the earlier case and the outcome, but in other cases, the Court reads the holding broadly to encompass both the outcome and the rationale articulated by the precedent-setting court. ${ }^{141}$ Professor

might be injured or coerced or who are situated in relationships where consent might not easily be refused. It does not involve public conduct or prostitution. It does not involve whether the government must give formal recognition to any relationship that homosexual persons seek to enter.” Lawrence v. Texas, 539 U.S. 558, 578 (2003).

136 Demisay, 508 U.S. at 592 n.5.

137 An exception might be ideological litigation, in which an interest group has more concern about advancing a particular agenda than the material interests at stake in the lawsuit.

138 See Parents Involved in Cmty. Schs. v. Seattle Sch. Dist. No. 1, 551 U.S. 701, 737 (2007) (plurality opinion) (quoting Cent. Va. Cmty. Coll. v. Katz, 546 U.S. 356, 363 (2006)) ("[W]e are not bound to follow our dicta in a prior case in which the point now at issue was not fully debated." (quoting $i d$.$) ).$

13919 U.S. (6 Wheat) 264 (1821).

$140 I d$. at 399-400.

141 See Michael C. Dorf, Dicta and Article III, 142 U. PA. L. Rev. 1997, 1999 (1994) (" $[\mathrm{F}]$ ederal courts sometimes treat the question whether a particular judicial statement is holding or dictum as a feature of the facts and outcome of the case, but other 
Dorf would prefer a policy of always reading the holding of an opinion to include the court's rationale, even when its reasoning would cover factual scenarios not present in the case at bar. ${ }^{142}$ The Justices, though, have often narrowly construed prior opinions, failing to embrace conclusions logically suggested by the earlier Court's reasoning.

Two examples from recent terms illustrate the point. Consider first the decision in Seminole Tribe of Florida $v$. Florida,${ }^{143}$ in which the Court concluded that a statute enacted by Congress under the Article I Indian Commerce Clause could not abrogate a state's sovereign immunity. ${ }^{144}$ The Court's rationale in Seminole Tribe seemingly extended to any legislation enacted under the Article I powers of Congress: "The Eleventh Amendment restricts the judicial power under Article III, and Article I cannot be used to circumvent the constitutional limitations placed upon federal jurisdiction." 145 The majority and dissenting opinions in Seminole Tribe therefore assumed that the holding of the case would also prevent Congress from abrogating state sovereign immunity based on the Article I Bankruptcy Clause. ${ }^{146} \mathrm{Nev}-$ ertheless, the Court reached the opposite conclusion when directly confronted with the Bankruptcy Clause issue in Central Virginia Community College v. Katz. ${ }^{147}$ Even though the rationale of Seminole Tribe would seem to encompass all Article I powers, the Katz majority concluded that mentions of the Bankruptcy Clause in Seminole Tribe represented nonbinding dicta. ${ }^{148}$

\footnotetext{
times they treat this question as a feature of the rationale of the prior opinion under analysis." (footnote omitted)).

142 See id. at 2040.

143517 U.S. 44 (1996).

144 See id. at 47.

145 Id. at 72-73; see also id. at 65-66 (distinguishing Fitzpatrick v. Bitzer, 427 U.S. 445 (1976), which permitted Congress to abrogate sovereign immunity under section 5 of the Fourteenth Amendment, because the Fourteenth Amendment "operated to alter the pre-existing balance between state and federal power achieved by Article III and the Eleventh Amendment.").

146 See Cent. Va. Cmty. Coll. v. Katz, 546 U.S. 356, 363 (2006) (opinions in Seminole Tribe "reflected an assumption that the holding in that case would apply to the Bankruptcy Clause"); Seminole Tribe, 517 U.S. at 77 \& n.1 (Stevens, J., dissenting) ("[The majority] prevents Congress from providing a federal forum for a broad range of actions against States, from those sounding in copyright and patent law, to those concerning bankruptcy, environmental law, and the regulation of our vast national economy.").

147546 U.S. at 359.

148 Id. at 363.
} 
To similar effect, consider the Court's decision in United States v. Miller, ${ }^{149}$ rejecting a Second Amendment challenge to an indictment for possession of a short-barreled shotgun. The Miller Court tied the Second Amendment's protection of "the right of the people to keep and bear Arms" to its recited purpose of maintaining a "well regulated Militia"150: "With obvious purpose to assure the continuation and render possible the effectiveness of such [militia] forces the declaration and guarantee of the Second Amendment were made. It must be interpreted and applied with that end in view."151 The Miller Court's rejection of the Second Amendment claim was based on an insufficient connection between the arms in question and a militia-related function:

In the absence of any evidence tending to show that possession or use of a "shotgun having a barrel of less than eighteen inches in length" at this time has some reasonable relationship to the preservation or efficiency of a well regulated militia, we cannot say that the Second Amendment guarantees the right to keep and bear such an instrument. ${ }^{152}$

The scope of Miller's holding became an issue in the later case of District of Columbia v. Heller, ${ }^{153}$ reviewing the District of Columbia's ban on possession of a handgun. A key point of contention in Heller was the precedential effect of Miller, which the dissenters read for the proposition that the Second Amendment "protects the right to keep and bear arms for certain military purposes, but . . . does not curtail the Legislature's power to regulate the nonmilitary use and ownership of weapons." 154 The Heller majority interpreted Miller more narrowly, understanding its holding to encompass only the proposition that the Second Amendment did not protect a particular type of weapon (a short-barreled shotgun), a limited conclusion that could be reconciled with the majority's view that the Second Amendment protects an individual's right to keep and bear certain arms for nonmilitia purposes like self-defense. ${ }^{155}$

Apart from President Obama's appointees, every recent member of the Supreme Court joined the majority in either Katz or Heller, even though each opinion arguably construed a prior decision more narrowly than the decision's rationale would indicate. The majority opin-

149307 U.S. 174 (1939).

150 U.S. Const. amend. II.

151 Miller, 307 U.S. at 178.

$152 I d$.

153554 U.S. 570 (2008).

$154 I d$. at 637 (Stevens, J., dissenting).

155 See id. at 621-22 (majority opinion). 
ion in Katz, authored by Justice Stevens, was also joined by Justices O'Connor, Souter, Ginsburg and Breyer. ${ }^{156}$ The majority opinion in Heller, authored by Justice Scalia, was joined by Chief Justice Roberts and Justices Kennedy, Thomas, and Alito. ${ }^{157}$ If the practice of narrowly construing prior holdings represents an unprincipled departure from the rule of stare decisis, then the charge of unprincipled decisionmaking can be leveled quite broadly, without regard to judicial ideology.

In my view, the respective majorities acted properly in both Katz and Heller when they narrowly read Seminole Tribe and Miller. ${ }^{158}$ Each Court's effort to distinguish holding from dictum can be seen as an application of Chief Justice Marshall's maxim that "general expressions, in every opinion, are to be taken in connection with the case in which those expressions are used," and "[i]f they go beyond the case ... ought not to control the judgment in a subsequent suit when the very point is presented for decision." 159 Seminole Tribe should not be understood to control the outcome in a case concerning abrogation of state sovereign immunity under the Bankruptcy Clause, even if some language in the opinion could be read to do so. The majority in Seminole Tribe may have assumed that its reasoning would continue to govern in the context of federal bankruptcy legislation, but it has no real complaint that a later Court chose to consider the question directly on the basis of plenary briefing and argument. An attempt by the Seminole Tribe Court to definitively resolve the Bankruptcy Clause issue in a case under the Indian Commerce Clause would have been overreaching.

Similarly, Miller should not be understood to control the outcome in a case involving application of the Second Amendment to possession of standard firearms in the home for self-defense, even if some language in the opinion could be read to do so. This is perhaps a closer question than the sovereign immunity example, since Miller and Heller both involved possession of weapons for nonmilitary use. However, as we will see in the sections that follow, the briefing in Miller and the opinion in that case were such that the Court should not be faulted for revisiting the meaning of the Second Amendment in a case presenting full briefing and argument on the merits. The case for narrowly construing a prior holding becomes stronger where

156 See Cent. Va. Cmty. Coll. v. Katz, 546 U.S. 356, 358 (2006).

157 See Heller, 554 U.S. at 572.

158 I am not defending the outcome reached by the majority opinions in Katz and Heller. I am merely defending each opinion's treatment of precedent.

159 Cohens v. Virginia, 19 U.S. (6 Wheat.) 264, 399 (1821). 
a court's reasoning could reach distinct issues that were not adequately briefed or argued by the parties.

\section{B. Inadequate Briefing, Argument, and Deliberation}

A number of Supreme Court opinions identify inadequate briefing and argument as a factor justifying denial of precedential effect to a legal proposition derived from an earlier opinion. ${ }^{160}$ For example, in United States v. L.A. Tucker Truck Lines, Inc., ${ }^{161}$ a party had challenged an administrative order on the ground that the examiner's appointment failed to satisfy requirements that the Administrative Procedure Act ${ }^{162}$ imposed. ${ }^{163}$ The government argued that the objection to the examiner's appointment was untimely, having first been raised in litigation to review the administrative order rather than the initial agency proceeding. ${ }^{164}$ The appellee replied that the timeliness question was foreclosed by Wong Yang Sung v. McGrath, ${ }^{165}$ in which a habeas corpus petitioner had raised the issue of Administrative Procedure Act compliance in challenging an earlier deportation order. ${ }^{166}$ The Supreme Court refused to treat Wong Yang Sung as dispositive on the timeliness question:

We need not inquire what should have been the result [in Wong Yang Sung] had the Government denied or the Court considered whether the objection there sustained was taken in time. The effect of the omission was not there raised in briefs or argument nor discussed in the opinion of the Court. Therefore, the case is not a binding precedent on this point. ${ }^{167}$

The Court thus indicated that the absence of briefing and argument played some role in the denial of stare decisis effect to Wong Yang Sung on the timeliness issue. The decision did not explain, though,

160 See, e.g., KVOS, Inc. v. Associated Press, 299 U.S. 269, 279 (1936) ("But in that case the answer did not challenge the jurisdiction, there was no assignment of error raising the question and no argument on the subject was presented to this court."); Williams v. United States, 289 U.S. 553, 570 (1933) ("The [Miles v. Graham] opinion therein contains no mention of the cases supposed to have been disapproved; nor does it show that this Court's attention was drawn to the question whether that court is a statutory court or a constitutional court. In fact, as appears from the briefs, that question was not mooted.").

161344 U.S. 33 (1952).

1625 U.S.C. $\$ \$ 551-559,701-706$ (2006).

163 See L.A. Tucker Truck Lines, 344 U.S. at 35.

164 See id.

165339 U.S. 33 (1950).

166 See L.A. Tucker Truck Lines, 344 U.S. at 37 (discussing Wong Yang Sung, 339 U.S. $33)$.

167 Id. at 37-38 (emphasis added). 
how much importance one should attribute to the lack of briefing in isolation.

If L.A. Tucker Truck Lines was the only relevant authority, one might see poor briefing and argument as merely a cumulative factor in stare decisis analysis. The Court paired the absence of briefing in Wong Yang Sung with what might be deemed a more important issue: the earlier Court's failure to discuss the timeliness question. Indeed, L.A. Tucker Truck Lines linked its stare decisis analysis to the longstanding principle that the Court "is not bound by a prior exercise of jurisdiction in a case where it was not questioned and it was passed sub silentio." 168 Given the obligation to raise jurisdictional issues sua sponte, if a court's unexplained exercise of jurisdiction does not count as precedent, then a fortiori a decision should not count as binding authority on other points the opinion fails to discuss. As the Court has written elsewhere: "Questions which merely lurk in the record, neither brought to the attention of the court nor ruled upon, are not to be considered as having been so decided as to constitute precedents." 169

Other case law makes clear, however, that lack of full briefing and argument, by itself, diminishes the precedential value of an opinion, even as to issues actually addressed by the Court. A good example is Hohn v. United States, ${ }^{170}$ in which the Court concluded that it may assert certiorari jurisdiction under the Antiterrorism and Effective Death Penalty Act (AEDPA) ${ }^{171}$ to review denial of a certificate of appealability. ${ }^{172}$ The Hohn Court had to deal with the stare decisis effect of House $v$. Mayo, a per curiam decision holding that the Court "lack[ed] statutory certiorari jurisdiction to review refusals to issue certificates of probable cause." ${ }^{173}$ The Supreme Court issues per

168 Id. at 38 \& $n .9$ (citing United States v. More, 7 U.S. (3 Cranch) 159, 172 (1805) and other cases).

169 Webster v. Fall, 266 U.S. 507, 511 (1925); accord Legal Servs. Corp. v. Velazquez, 531 U.S. 533, 557 (2001) (Scalia, J., dissenting) ("Judicial decisions do not stand as binding 'precedent' for points that were not raised, not argued, and hence not analyzed.”); Plaut v. Spendthrift Farm, Inc., 514 U.S. 211, 232 n.6 (1995) (“Of course the unexplained silences of our decisions lack precedential weight.”); see also Lopez v. Monterey Cnty, 525 U.S. 266, 281 (1999) (ruling that the court was not bound by prior assumptions, but routine assumption by courts and parties about statute's meaning supported that reading).

170524 U.S. 236 (1998).

171 Antiterrorism and Effective Death Penalty Act, Pub. L. No. 104-132, 110 Stat. 1214 (codified as amended in scattered sections of 8, 18, 28, 40, 42 U.S.C.).

172 Hohn, 524 U.S. at 253.

173 Id. at 251 (overruling, as to this issue, House v. Mayo, 324 U.S. 42, 44 (1945) (per curiam)). 
curiam opinions like House $v$. Mayo summarily, on the basis of the initial certiorari or appeal briefing, without full briefing and argument on the merits. The Hohn Court acknowledged that the per curiam opinion in House was "in direct conflict" with its decision to exercise jurisdiction, ${ }^{174}$ but it declined to follow the earlier ruling. The Hohn majority explained: "[W]e have felt less constrained to follow precedent where, as here, the opinion was rendered without full briefing or argument." 175

Hohn relied on Gray v. Mississippi, ${ }^{176}$ which acknowledged that " $[\mathrm{t}]$ he Court . . . at times has said that summary action . . does not have the same precedential effect as does a case decided upon full briefing and argument."177 Nonmajority opinions have likewise recognized this limitation on stare decisis. Justice Souter, for instance, has said that " $[\mathrm{s}]$ ound judicial decisionmaking requires 'both a vigorous prosecution and a vigorous defense' of the issues in dispute and a constitutional rule announced sua sponte is entitled to less deference than one addressed on full briefing and argument."178 Justice Brennan criticized the Court's departure from stare decisis in another case because " $[n]$ one of the reasons we have hitherto deemed necessary for departing from the doctrine of stare decisis are present," such as that the rejected decision "proceeded from inadequate briefing or argumentation." 179

The quality of briefing and argument does not just affect the weight attributed to a prior decision under stare decisis principles, but can also help determine the scope of the earlier precedent. In other words, the Court seems less inclined to read a prior decision's holding to include aspects of the opinion that were not based on plenary briefing. In Katz, for instance, in concluding that Seminole Tribe should not control abrogation of sovereign immunity under the Bankruptcy Clause, the Court did not feel "bound to follow our dicta in a prior

175 Id. The Hohn Court noted that stare decisis has "special force in the area of statutory interpretation." Id. (quoting Patterson v. McLean Credit Union, 491 U.S. 164, 172-73 (1989)). However, it said that the doctrine's role is "somewhat reduced" in the context of a procedural rule. Id. (quoting United States v. Gaudin, 515 U.S. $506,521(1995))$. It also noted that the rule in House had not been consistently followed by the Court. Id. at 252. omitted) (quoting Christianburg Garment Co. v. EEOC, 434 U.S. 412, 419 (1978)).

179 Teague v. Lane, 489 U.S. 288, 332 (1989) (Brennan, J., dissenting).
} 
case in which the point now at issue was not fully debated."180 Having experienced the benefit of "[c]areful study and reflection," the Katz majority felt free to reconsider the language about bankruptcy cases in the Seminole Tribe opinions. ${ }^{181}$

The Heller majority was even more explicit about the inadequacy of the Miller briefing as a justification for its narrow reading of that opinion. The available briefing in Miller-which came from only one party-paid little attention to Second Amendment history and, hence, would not support broad conclusions about the amendment's meaning:

The defendants made no appearance in the case, neither filing a brief nor appearing at oral argument; the Court heard from no one but the Government (reason enough, one would think, not to make that case the beginning and the end of this Court's consideration of the Second Amendment). The Government's brief spent two pages discussing English legal sources .... The Government's Miller brief thus provided scant discussion of the history of the Second Amendment-and the Court was presented with no counterdiscussion. ${ }^{182}$

As a result of the substandard briefing, the Miller opinion said nothing "about the history of the Second Amendment."183 Consequently, the opinion could not be read as a definitive resolution of the broader question addressed in Heller about the Second Amendment's meaning.

We see then that inadequate briefing and argument can interact with the law of precedent in two distinct ways. As in Hohn, inadequate briefing can give a reason for according less weight to a prior Court's holding. Alternatively, as in Katz and Heller, inadequate briefing can be a reason for reading a prior precedent narrowly, treating the holding as less expansive than it might have seemed. Both aspects of the law of precedent make sense in light of the nature of stare decisis and the purposes served by briefing and argument in the decisionmaking process. Stare decisis offers a short cut, eliminating the need for extended analysis of a legal issue previously resolved by the judiciary. A court can save time and effort by citing legal conclusions from an earlier opinion as settled for purposes of resolving the present litigation. ${ }^{184}$ However, requiring courts to rely on the work of their predecessors makes less sense if we have reason to distrust the legal analysis

180 Cent. Va. Cmty. Coll. v. Katz, 546 U.S. 356, 363 (2006).

181 See id.

182 Dist. of Columbia v. Heller, 554 U.S. 570, 623-34 (2003) (citations omitted).

$183 I d$. at 624.

184 See CARdozo, supra note 6, at 149 ("[T] he labor of judges would be increased almost to the breaking point if every past decision could be reopened in every case, 
in the earlier opinion. The fact that briefing and argument in the earlier case were inadequate tends to undermine confidence in the legal conclusion reached by the precedent-setting court. Since we believe briefing and argument helps a court reach more reliable conclusions, we put correspondingly less faith in legal conclusions reached without the benefit of full briefing and argument. Similarly, as in Hohn, we place less confidence in per curiam opinions because the Court puts less effort into cases decided summarily, making such decisions less reliable than those that resulted from plenary review. ${ }^{185}$

Recognition of the purposes served by briefing and argument can help to assess the importance of briefing quality in determining the precedential weight of a particular opinion. In some cases, substandard briefing may be outweighed by other factors in the stare decisis analysis. For instance, notwithstanding the inadequate briefs in Southland Corp. v. Keating, ${ }^{186}$ a majority of the Supreme Court decided on stare decisis grounds to adhere to Southland's conclusion that the Federal Arbitration $\mathrm{Act}^{187}$ applies in state courts, preempting contrary state law:

Nothing significant has changed in the 10 years subsequent to Southland; no later cases have eroded Southland's authority; and no unforeseen practical problems have arisen. Moreover, in the interim, private parties have likely written contracts relying upon Southland as authority. Further, Congress, both before and after Southland, has enacted legislation extending, not retracting, the scope of arbitration. ${ }^{188}$

With respect to the briefing factor in particular, Justice Breyer noted that the Southland majority had "recognized that the pre-emption issue was a difficult one, and it considered the basic arguments that respondents and amici now raise (even though those issues were not

and one could not lay one's own course of bricks on the secure foundation of the courses laid by others who had gone before him.").

185 See Gressman ET AL., supra note 106, at 305 ("[T] he fact that the Court devotes less time and thought to appeals disposed of summarily would in itself warrant the inference that the Justices feel less intellectual commitment to such decisions, even though they are a disposition on the merits.").

186465 U.S. 1 (1984).

1879 U.S.C. $\$ \S 1-16(2006)$.

188 Allied-Bruce Terminix Cos., Inc. v. Dobson, 513 U.S. 265, 272 (1995) (declining to overrule Southland Corp. v. Keating, 465 U.S. 1 (1984)); see also id. at 283-84 (O'Connor, J., concurring) (acquiescing in erroneous Southland decision based on reliance and other stare decisis considerations). But see id. at 295-96 (Thomas, J., dissenting) (arguing that the costs of overruling Southland are not unacceptable and state court autonomy provides special justification for reconsideration). 
thoroughly briefed at the time)."189 In these circumstances, incomplete briefing in Southland seemed less significant than other stare decisis factors-such as reliance-since the poor briefing did not prevent the Court from considering the principal arguments for a conclusion contrary to the one the Court reached. ${ }^{190}$

\section{Unreasoned or Badly Reasoned Opinions}

Just as the Supreme Court has applied the law of precedent to deny or minimize stare decisis effect when a ruling resulted from a substandard decisionmaking process, it has also used the law of precedent to enforce the discipline of careful opinion writing. Here our analysis will divide into three broad categorizations. First, we will see that when the Court has summarily disposed of a case without an opinion, it has read the resulting holding particularly narrowly and has afforded that holding diminished precedential force. While the Court has recognized some precedential impact for its unexplained summary dispositions, it has treated the absence of an opinion as a reason to significantly limit both the scope and the weight of the resulting precedent for stare decisis purposes. Second, where an opinion purported to resolve or assumed the answer to a legal question, but the analysis was conclusory or the reasoning scanty, the Court has felt free to revisit the issue in a later case squarely presenting the question. Third, in cases involving a full opinion on the merits of a legal question, the Court has indicated that it is appropriate to reconsider earlier precedent that was "badly reasoned."

\section{Dispositions Without Opinions}

Before 1988, the Supreme Court operated under a significantly broader mandatory jurisdiction than at present. The Court was required to issue rulings in many appeals that today would simply be avoided through denial of a petition for writ of certiorari. ${ }^{191}$ Because the volume of such mandatory appeals did not permit full briefing and argument in every case, the Court adopted the practice of summarily affirming many lower court decisions and summarily dismissing

$189 I d$. at 272 (majority opinion).

190 The fact that Southland was a statutory case presumably also influenced the Court's stare decisis calculus, since Congress could have corrected any error in Southland's analysis through a statutory amendment. See Pearson v. Callahan, 552 U.S. 223, 227 (2009) (" $[\mathrm{C}]$ onsiderations of stare decisis weigh heavily in the area of statutory construction, where Congress is free to change this Court's interpretation of its legislation." (quoting Ill. Brick Co. v. Illinois, 431 U.S. 720, 736 (1977))).

191 See Gressman et Al., supra note 106, at 298-300. 
others for want of a substantial federal question. These summary affirmances and dismissals were routinely issued without any opinion from the Court explaining its disposition. ${ }^{192}$

Though the method of handling these mandatory appeals was comparable in some respects to the method of handling petitions for certiorari, ${ }^{193}$ the Court's summary rulings in such appeals have been deemed decisions on the merits. ${ }^{194}$ Lower courts therefore needed to know whether the Court's summary dispositions were entitled to precedential effect under rules of stare decisis. The Supreme Court answered in the affirmative in Hicks $v$. Mirand $a,{ }^{195}$ concluding that a dismissal for want of a substantial federal question constitutes a decision on the merits, and that a lower court therefore erred in disregarding such a ruling when it resolved a case raising related issues. ${ }^{196}$ The proper course, the Court indicated, would be for the lower court to "ascertain what issues had been properly presented [to the Supreme Court] and declared by this Court to be without substance" and then to decide whether the issues in the two cases "were sufficiently the same" to make the summary dismissal a "controlling precedent." 197 The Court acknowledged, though, that "[a]scertaining the reach and content of summary actions may itself present issues of real substance."198

The Court revisited the precedential effect of summary dispositions in Mandel $v$. Bradley, ${ }^{199}$ clarifying that the holding of such a decision must be read narrowly to reject only "the specific challenges presented in the statement of jurisdiction." ${ }^{200}$ Mandel involved a dispute over Maryland's requirements for ballot access by independent candidates not associated with a major political party. The lower federal court in Mandel had concluded that its decision was controlled by

192 See, e.g., Bomhardt v. Maryland, 485 U.S. 950 (1988) (dismissing without opinion "for want of [a] substantial federal question"); City of Manassas, Virginia v. United States, 485 U.S. 1017 (1988) (affirming the judgment without opinion).

193 See Gressman ET AL., supra note 106, at 298-99 (noting that most appeals were decided without full briefing or oral argument); $i d$. at 300-04 (discussing factors that might influence the Court's decision whether to order full briefing and argument).

194 See id. at 304-10.

195422 U.S. 332 (1975).

196 See id. at 343-44.

197 Id. at 345 n.14.

198 Id. The Supreme Court concluded that the case was within its jurisdiction notwithstanding the lower court's failure to take account of the earlier summary dismissal. See id. at 345-46. The Court then resolved the case on other grounds. See id. at 348-52.

199432 U.S. 173 (1977).

$200 \quad$ Id. at $176-77$. 
the Supreme Court's summary affirmance in Tucker $v$. Salera ${ }^{201}$ of a lower court decision striking down Pennsylvania's ballot access statute. ${ }^{202}$ The Supreme Court in Mandel decided that the court below had read Salera too broadly. Summary dispositions "prevent lower courts from coming to opposite conclusions on the precise issues presented and necessarily decided" by the Court. ${ }^{203}$ But when a summary disposition affirms the judgment of the court below, it does not necessarily embrace the lower court's reasoning. ${ }^{204}$ Such a decision should not be read to break new ground, and its "precedential significance" should be "assessed in the light of all of the facts in that case."205 Given that there was a significant difference between the statutes in Salera and Mandel — the Pennsylvania statute had a "21-day limitation on signature gathering," while the Maryland statute contained no such limit-the summary affirmance in Salera could not be read as controlling the outcome in Mandel. ${ }^{206}$

Mandel shows that the absence of an opinion dramatically constricts the scope of the resulting precedent. Under the law of precedent, courts narrowly construe the holding of a Supreme Court case decided summarily without an accompanying rationale. Other authority indicates that the absence of an opinion greatly minimizes a decision's precedential weight as well. The Supreme Court has said that "summary affirmances have considerably less precedential value than an opinion on the merits." 207 Thus, "upon fuller consideration of an issue under plenary review, the Court has not hesitated to discard a rule which a line of summary affirmances may appear to have established."208 For instance, in Usery v. Turner Elkhorn Mining Co., ${ }^{209}$ the Court, "having heard oral argument and entertained full briefing," decided to give plenary consideration to issues that had already been resolved through summary affirmance in an earlier case. ${ }^{210}$

\footnotetext{
201424 U.S. 959 (1976).

202 See Mandel, 432 U.S. at 175 (discussing Tucker, 424 U.S. 959, which summarily affirmed Salera v. Tucker, 399 F. Supp. 1258 (E.D. Pa. 1975)).

203 Id. at 176.

204 See id. (quoting Fusari v. Steinberg, 419 U.S. 379, 391-92 (1975) (Burger, C.J., concurring) ("When we summarily affirm, without opinion, . . . we affirm the judgment but not necessarily the reasoning by which it was reached.")).

205 Id. at 177.

206 See id.

207 Ill. State Bd. of Elections v. Socialist Workers Party, 440 U.S. 173, 180-81 (1979).

208 Id. at 181 (quoting Fusari, 419 U.S. at 392 (Burger, C.J., concurring)).

209428 U.S. 1 (1976).

210 See id. at 14 (reconsidering issues resolved in Nat'l Indep. Coal Operators Ass'n v. Brennan, 372 F. Supp. 16 (D.D.C. 1974), aff'd 419 U.S. 955 (1974)).
} 
\begin{tabular}{lllll}
\hline |jciprod01〉productnWNINDL187-4WDL402.txt & unknown & Seq: 38 & 29-MAY-12 & $12: 28$ \\
\hline
\end{tabular}

$144^{2}$

NOTRE DAME LAW REVIEW

[VOL. $87: 4$

The diminished precedential force of rulings issued without opinion can be seen in Edelman v. Jordan, ${ }^{211}$ which held that the Eleventh Amendment bars retroactive monetary relief in an action against a state official where the award would be paid from state funds. ${ }^{212}$ While the Court thought this result consistent with some of its earlier precedent, it also had to overrule four previous decisions approving such retroactive relief. In Shapiro v. Thompson, ${ }^{213}$ an Eleventh Amendment objection to retroactive relief had been presented in a case subject to oral argument, though the Court, "while affirming the judgment, did not in its opinion refer to or substantively treat the Eleventh Amendment argument."214 In three other cases, the Court had summarily affirmed awards of retroactive relief "notwithstanding Eleventh Amendment contentions made by state officers who were appealing from the District Court judgment." 215 The Edelman Court decided it was not bound to follow these four earlier rulings:

This case . . . is the first opportunity the Court has taken to fully explore and treat the Eleventh Amendment aspects of such relief in a written opinion. Shapiro $v$. Thompson and these three summary affirmances obviously are of precedential value in support of the contention that the Eleventh Amendment does not bar the relief awarded by the District Court in this case. Equally obviously, they are not of the same precedential value as would be an opinion of this Court treating the question on the merits. . . Having now had an opportunity to more fully consider the Eleventh Amendment issue after briefing and argument, we disapprove the Eleventh Amendment holdings of those cases to the extent that they are inconsistent with our holding today. ${ }^{216}$

Cases like Usery and Edelman not only show the reduced precedential impact of decisions rendered without an opinion, but also reinforce the point made in the previous section, that the absence of plenary briefing and argument diminishes the weight of a precedent for stare decisis purposes. ${ }^{217}$

\footnotetext{
211415 U.S. 651 (1974).

212 See id. at 668-69.

213394 U.S. 618 (1969).

214 Edelman, 415 U.S. at 670 (discussing Shapiro, 394 U.S. at 618).

215 Id. (citing State Dep't of Health \& Rehab. Servs. v. Zarate, 407 U.S. 918 (1972), aff'g 347 F. Supp. 1004 (S.D. Fla. 1971); Sterrett v. Mothers' \& Children's Rights Org., 409 U.S. 809 (1972), aff'g unreported order (N.D. Ind. 1972); Wyman v. Bowens, 397 U.S. 49 (1970), aff'g Gaddis v. Wyman, 304 F. Supp. 717 (S.D.N.Y. 1969)).

$216 I d$. at 670-71. Part of the Court's reasoning was that stare decisis presents less of a constraint on constitutional adjudication than in other areas of law. See id. at 671 . 217 See supra Part II.B.
} 
The stare decisis treatment of summary dispositions highlights some of the competing values underlying the law of precedent. To the extent the rule of stare decisis seeks to promote the rule of law, preserve judicial resources, ensure that like cases receive like treatment, ${ }^{218}$ and protect reliance on prior judicial rulings, one can see why the Court would treat such summary dispositions as having precedential force. At the same time, the fact that a ruling without opinion incurs significantly less respect than a plenary opinion issued after full briefing and argument shows that other values are at stake in the law of precedent. The values supporting treatment as precedent must be balanced against competing values, and such precedents will often yield in the face of a judicial desire to give a legal question more careful consideration in light of adversarial briefing.

\section{Conclusory or Cursory Opinions}

It is not just in the context of summary dispositions that the values promoted by the discipline of writing careful judicial opinions can trump other values served by the rule of stare decisis. We saw earlier that the majority in District of Columbia $v$. Heller adopted a narrow reading of the holding in United States v. Miller, in part because the briefing in Miller was inadequate to allow broad pronouncements about the meaning of the Second Amendment. The Court's restricted reading of Miller was also premised on the sparse analysis offered in the opinion:

It is particularly wrongheaded to read Miller for more than what it said, because the case did not even purport to be a thorough examination of the Second Amendment. . . . [T] he text of the Court's opinion ... discusses none of the history of the Second Amendment. It assumes from the prologue that the Amendment was designed to preserve the militia (which we do not dispute), and then reviews some historical materials dealing with the nature of the militia, and in particular with the nature of the arms their members were expected to possess. Not a word (not a word) about the history of the Second Amendment. This is the mighty rock upon which the dissent rests its case. ${ }^{219}$

In discounting the reliance prior courts had supposedly placed on the earlier decision, the Heller majority responded, "If so, they

218 See Cardozo, supra note 6, at 34 ("Adherence to precedent must then be the rule rather than the exception if litigants are to have faith in the even-handed administration of justice in the courts.").

219 Dist. of Columbia v. Heller, 554 U.S. 570, 623-24 (2008) (citations omitted). 
overread Miller."220 The majority thus suggested that any courts that relied on Miller as a definitive exposition of the Second Amendment had treated dicta as holding and placed "erroneous reliance upon an uncontested and virtually unreasoned case."221 Heller illustrates that, notwithstanding broad language, the scope of a prior holding can be restricted if it dealt with the issues in a cursory fashion reflecting incomplete consideration or a failure to grapple with the complexities presented.

As with inadequate briefing, incomplete analysis of an issue can affect not only a precedent's scope, but also its weight. In this vein, the Court has felt free to revisit a legal question where the answer has been assumed in prior cases, but never "squarely addressed."222 For instance, in Brecht $v$. Abrahamson, ${ }^{223}$ the Court considered the appropriate harmless error standard to apply when a habeas petitioner claimed that the prosecution had improperly commented on the defendant's failure to testify in violation of the Fifth Amendment privilege against self-incrimination. In at least four prior habeas corpus cases raising such a claim, the Court had employed the same harmless error standard applied on direct review. ${ }^{224}$ The petitioner argued that the Court was "bound by these habeas cases, by way of stare decisis," so that it could not adopt a less stringent harmless error standard in his case. ${ }^{225}$ The majority responded that "since we have never squarely addressed the issue, and have at most assumed the applicability of the [direct review] standard on habeas, we are free to address the issue on the merits." 226

A more revealing case illustrating the diminished precedential weight of cursory or incomplete analysis is Copperweld Corp. v. Independence Tube Corp., ${ }^{227}$ an antitrust case concluding that a parent corporation cannot conspire with its wholly owned subsidiary. ${ }^{228}$ The Court in Copperweld faced a number of prior decisions recognizing an "intraenterprise conspiracy doctrine," pursuant to which "liability is not foreclosed merely because a parent and its subsidiary are subject to

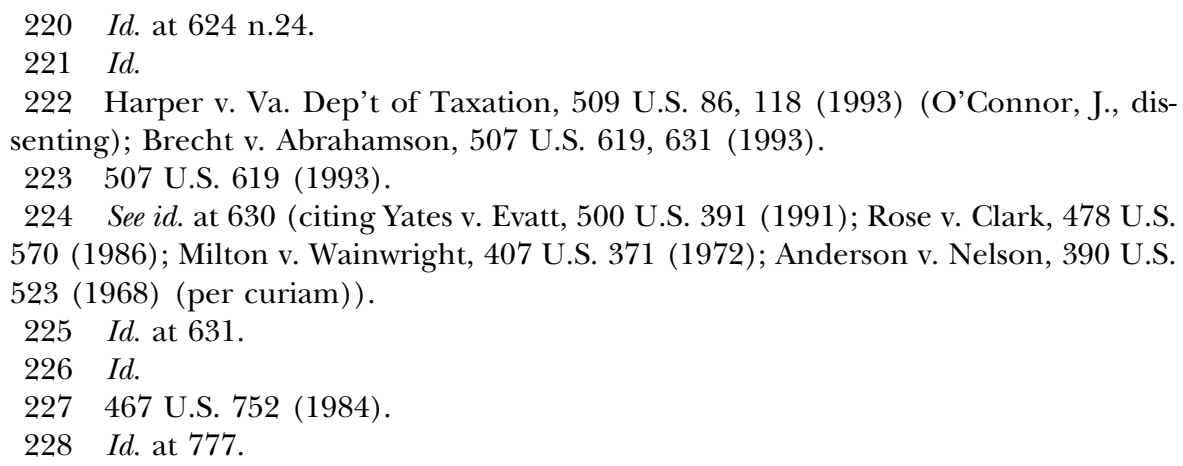


common ownership."229 Surveying the prior cases, the majority stated:

In no case has the Court considered the merits of the intra-enterprise conspiracy doctrine in depth. Indeed, the concept arose from a far narrower rule. Although the Court has expressed approval of the doctrine on a number of occasions, a finding of intra-enterprise conspiracy was in all but perhaps one instance unnecessary to the result. ${ }^{230}$

The Copperweld Court acknowledged one prior case, involving two wholly owned subsidiaries of the same parent, in which application of the intra-enterprise conspiracy doctrine had been necessary to the outcome. ${ }^{231}$ That opinion "offhandedly dismissed" the argument that parents and wholly owned subsidiaries could not conspire with one another and "failed to confront the anomalies an intra-enterprise doctrine entails."232 Given that the cases had "never explored or analyzed in detail the justifications for such a rule," the Court felt free to reexamine the doctrine in the context of a parent and a wholly owned subsidiary. ${ }^{233}$ In other words, the respect due a legal conclusion under the principle of stare decisis depends in part on the effort the court has put into defending its outcome.

It makes sense that incomplete or superficial analysis would affect the weight and scope of a precedent for stare decisis purposes. As suggested above, written opinions improve the quality of judicial decisionmaking, promote judicial accountability, and build public confidence in the judicial system. When a court's opinion is cursory or simplistic, failing to grapple with complexities of an issue or consider possible counterarguments, we have less reason for confidence that the court did the work necessary to reach a reliable conclusion and therefore less reason to defer to the court's decision.

\section{Badly Reasoned Opinions}

In addition to cases where the reasoning was cursory or sparse, the Court has also said that it is appropriate to reconsider a precedent that was "badly reasoned," ${ }^{344}$ repeatedly citing Smith v. Allwright ${ }^{235}$ in 
support of this proposition. ${ }^{236}$ In Smith, the Court overruled Grovey v. Townsend, ${ }^{237}$ which approved the Texas Democratic Party's practice of holding whites-only primary elections. ${ }^{238}$ Grovey followed earlier decisions striking down a Texas statute that permitted only whites to vote in the Democratic Party primary ${ }^{239}$ and a later statute that allowed the party's state executive committee to determine primary voter eligibility. ${ }^{240}$ In Grovey, by contrast, the Court upheld a resolution adopted by the state Democratic Party convention, limiting party membership to only white citizens. ${ }^{241}$ Even on the assumption that selection as the Democratic Party candidate was tantamount to prevailing in the general election, the Grovey Court thought it important not to "confuse the privilege of membership in a party with the right to vote for one who is to hold a public office."242 According to the Court, the state was constitutionally bound to preserve the voting rights of African American citizens, but party membership was a private matter with which "the state need have no concern." 243

The Supreme Court revisited the Texas all-white primary system in Smith, concluding that the close connection between the primary and the general election meant that the Fifteenth Amendment applied to the former as well as the latter:

When primaries become a part of the machinery for choosing officials, state and national, as they have here, the same tests to determine the character of discrimination or abridgement should be applied to the primary as are applied to the general election. If the state requires a certain electoral procedure, prescribes a general election ballot made up of party nominees so chosen and limits the choice of the electorate in general elections for state offices, practically speaking, to those whose names appear on such a ballot, it endorses, adopts and enforces the discrimination against Negroes, practiced by a party entrusted by Texas law with the determination of the qualifications of participants in the primary. This is state action within the meaning of the Fifteenth Amendment. ${ }^{244}$

235321 U.S. 649 (1944).

236 See, e.g., Int'l Bus. Machs. Corp., 517 U.S. at 856; Seminole Tribe of Fla. v. Florida, 517 U.S. 44, 63 (1996); Payne, 501 U.S. at 827.

237295 U.S. 45 (1935).

238 See Allwright, 321 U.S. at 664-66 (overruling Grovey, 295 U.S. 45).

239 See Nixon v. Herndon, 273 U.S. 536, 540-41 (1927).

240 See Nixon v. Condon, 286 U.S. 73, 89 (1932).

241 See Grovey, 295 U.S. at 47, 55.

242 Id. at 55.

243 Id.

244 Smith v. Allwright, 321 U.S. 649, 664 (1944) (citing Guinn v. United States, 238 U.S. 347, 362 (1915)). 
The Smith Court concluded that the principle of stare decisis did not bind it to follow Grovey: "In reaching this conclusion we are not unmindful of the desirability of continuity of decision in constitutional questions. However, when convinced of former error, this Court has never felt constrained to follow precedent."245

The Court has not explained its suggestion that Smith shows the overruling of a "badly reasoned" precedent, ${ }^{246}$ but the thought process is not hard to envision. The Grovey Court's conclusion that the discrimination practiced against African American citizens was purely a private matter of party membership ignored the larger pattern of state support for such discrimination. The scheme considered in Grovey followed earlier state-supported attempts to exclude nonwhites from the electoral process. When viewed in light of the larger historical context, the arrangement reviewed by the Grovey Court can be recognized as one more in a series of collusive attempts by the State of Texas and the Democratic Party to violate the Fifteenth Amendment. Adhering to Grovey in light of Texas' continuing lawlessness could have done more to undermine the rule of law than altering a myopic constitutional conclusion reached by the Court in an earlier opinion.

\section{Application to Future Supreme Court Cases}

We have seen that the Supreme Court uses the law of precedent to police decisionmaking by previous Courts. The Court sometimes declines to follow dicta that go beyond the issues in the earlier litigation. It also narrowly construes prior holdings or accords diminished precedential weight where the precedent-setting Court acted without plenary briefing and argument, or failed to offer an adequate explanation for a legal conclusion. In this section of the Article, we consider the potential application of these principles in the context of three issues likely to come before the Supreme Court: (1) the constitutionality of laws excluding same-sex couples from the definition of "marriage," (2) the scope of supervisory liability for constitutional violations by subordinates, and (3) state regulation of abortion prior to fetal viability.

\section{A. Baker v. Nelson and Same-Sex Marriage}

A number of cases in recent years have involved state or federal constitutional challenges to laws defining "marriage" in terms of male-

$245 I d$. at 665 (footnote omitted).

246 See supra text accompanying notes 234-36. 
female relationships. ${ }^{247}$ Federal constitutional challenges often invoke the Due Process Clause or the Equal Protection Clause of the Fourteenth Amendment. ${ }^{248}$ The Supreme Court first addressed the constitutionality of excluding same-sex couples from state marriage laws in its 1972 summary disposition in Baker v. Nelson. ${ }^{249}$ In Baker, two males challenged a Minnesota court clerk's refusal to issue a marriage license. ${ }^{250}$ The Minnesota Supreme Court ruled that Minnesota law did not authorize marriage by persons of the same sex and that denial of the marriage license did not violate federal constitutional rights. ${ }^{251}$ The same-sex couple then took an appeal to the United States Supreme Court, invoking the Court's mandatory jurisdiction. ${ }^{252}$ The Jurisdictional Statement presented three questions:

1. Whether appellee's refusal to sanctify appellants' marriage deprives appellants of their liberty to marry and of their property without due process of law under the Fourteenth Amendment.

2. Whether appellee's refusal, pursuant to Minnesota marriage statutes, to sanctify appellants' marriage because both are of the male sex violates their rights under the Equal Protection Clause of the Fourteenth Amendment.

3. Whether appellee's refusal to sanctify appellants' marriage deprives appellants of their right to privacy under the Ninth and Fourteenth Amendments. ${ }^{253}$

In response to a motion filed by the appellee, ${ }^{254}$ the Court dismissed the appeal without a written opinion "for want of [a] substantial federal question.”255

A recurring issue in subsequent litigation concerning same-sex marriage has been the precedential effect of the Court's summary dismissal in Baker. As noted above, the Court has taken the position that

247 See, e.g., Jesse McKinley, Closing Arguments in Marriage Trial, N.Y. Times, at A15 (June 17, 2010).

248 See, e.g., Perry v. Schwarzenegger, 704 F. Supp. 2d 921 (N.D. Cal. 2010) (finding that California's Proposition 8, returning California law to the traditional definition of marriage, violated Due Process and Equal Protection Clauses), aff'd sub nom. Perry v. Brown, 671 F.3d 1052 (9th Cir. 2012).

249409 U.S. 810 (1972).

250 See Baker v. Nelson, 191 N.W.2d 185, 185 (Minn. 1971), appeal dismissed, 409 U.S. 810 (1972).

251 See id. at 186-87.

252 See Statement of Jurisdiction at 2, Baker v. Nelson, 191 N.W.2d (Feb. 11, 1972).

253 Id. at 3.

254 See Appellee's Motion to Dismiss Appeal and Brief, Baker v. Nelson, 191

N.W.2d (Mar. 10, 1972).

255 Baker, 409 U.S. 810. 
a summary disposition constitutes a decision on the merits and should generally be treated as binding precedent on issues raised by the jurisdictional statement and necessarily resolved in disposing of the appeal. ${ }^{256}$ Consequently, a number of lower courts have viewed Baker as a binding precedent conclusively rejecting claims seeking to establish a right to same-sex marriage under the United States Constitution. ${ }^{257}$ Other courts have declined to treat Baker as dispositive, either on the theory that the issues differed in the two lawsuits, ${ }^{258}$ or that the intervening decision in Lawrence $v$. Texas ${ }^{259}$ altered the relevant analysis. ${ }^{260}$

If the United States Supreme Court is again asked in a future case to address the constitutionality of the traditional definition of marriage, it could resolve the question on the basis of stare decisis, citing Baker for the proposition that traditional marriage laws do not violate equal protection principles or fundamental rights guaranteed by the Fourteenth Amendment. Such a decision would serve many of the values underlying the law of precedent. It would preserve stability in

256 See supra notes 193-200 and accompanying text.

257 See, e.g., McConnell v. United States, 188 Fed. App’x 540, 542 (8th Cir. 2006) (raising same issue resolved in Baker); Citizens for Equal Protection v. Bruning, 455 F.3d 859, 870-71 (8th Cir. 2006) (stating there was a good reason for the restraint displayed in Baker); Wilson v. Ake, 354 F. Supp. 2d 1298, 1304-05 (M.D. Fla. 2005) (holding that Baker constitutes binding precedent requiring dismissal of case); Adams v. Howerton, 486 F. Supp. 1119, 1124 (C.D. Cal. 1980) (stating that Baker was controlling, but that court would reach same conclusion de novo); Lockyer v. City of San Francisco, 95 P.3d 459, 504 (Cal. 2004) (stating that Baker sets forth federal constitutional law with respect to same-sex marriage, and not undermined by Lawrence); Morrison v. Sadler, 821 N.E.2d 15, 19-20 (Ind. App. 2005) (stating that Baker shows Court did not think Loving supported argument by same-sex couples); Langan v. St. Vincent's Hosp., 802 N.Y.S.2d 476, 478 (App. Div. 2005) (finding Baker binding precedent on equal protection issue); Andersen v. King Cnty., 138 P.3d 963, 999 (Wash. 2006) (following Baker in rejecting claim of constitutional right to same-sex marriage); see also Hernandez v. Robles, 855 N.E.2d 1, 17 n.4 (N.Y. 2006) (noting that Baker was decided after Loving, and shows that the federal due process right to marriage did not extend to same-sex couples; however, does not resolve issue under state due process clause).

258 See, e.g., Smelt v. Cnty. of Orange, 374 F. Supp.2d 861, 872-73 (C.D. Cal. 2005), aff'd in part, vacated in part, remanded, 447 F.3d 673 (9th Cir. 2006), cert. denied, 549 U.S. 959 (2006) (holding the validity of state marriage law in Baker distinct from issue of constitutionality of federal Defense of Marriage Act (DOMA)); In re Kandu, 315 B.R. 123, 138 (Bankr. W.D. Wash. 2004) (stating that Baker is not binding precedent in case concerning DOMA).

259539 U.S. 558 (2003).

260 See, e.g., Kandu, 315 B.R. at 138 (stating that Baker was not binding in part because of potential impact of subsequent Supreme Court decisions, particularly Lawrence). 
the law, foreclosing the potentially destabilizing impact of a decision fundamentally restructuring an important social institution. It would protect reliance interests of governmental bodies that have enacted spousal benefits legislation or employers who have entered contractual commitments in light of Baker's affirmation of traditional marriage rules.

In my view, however, the Court should not resolve such a future case based solely on the precedential authority of Baker. Notwithstanding the benefits of adherence to precedent, the circumstances surrounding the ruling in Baker suggest that the decision does not merit treatment equivalent to a considered decision of the Court. To begin with, Baker was resolved without full briefing and argument. The jurisdictional statement and the appellee's brief, incorporating by reference the opinion of the Minnesota Supreme Court, offered a competent summary of the constitutional issues. ${ }^{261}$ Nevertheless, plenary briefing and argument would have permitted more extensive development of the questions in dispute. More importantly, setting the case for oral argument would have guaranteed extended consideration of the constitutional questions surrounding same-sex marriage over a period of months. Instead, the Court resolved the case through a procedure akin to the process for a denial of certiorari.

The absence of a written opinion in Baker offers an additional reason to deny controlling effect to the decision in future Supreme Court proceedings on the issue. Even if the Court had thoroughly considered the constitutional issues raised in Baker, it offered no written explanation for the decision dismissing the appeal. ${ }^{262}$ The Justices thus avoided the disciplinary effect of writing a reasoned opinion and the accountability ensured by internal and external scrutiny of the majority's explanation for a constitutional ruling. Resolution of an issue with significant consequences for the parties and the public merits more than a one-sentence, unexplained rejection of the arguments advanced.

To argue that the Court should not treat Baker as controlling its decision through the force of stare decisis does not necessarily mean Baker would be irrelevant in proceedings seeking to establish a right to same-sex marriage. Decisions that do not control the outcome of a case may nevertheless be treated as persuasive authority. Perhaps the Supreme Court's alacrity in rejecting constitutional arguments for

261 See Statement of Jurisdiction, supra note 252, at 11-19; Appellee's Motion to Dismiss Appeal and Brief, supra note 254, at 3-7; see also id. at 9-14 (opinion of Minnesota Supreme Court).

262 See Baker v. Nelson, 409 U.S. 810, 810 (1972). 
same-sex marriage less than forty years ago might have some bearing on the issue of whether a rational basis exists for laws limiting marriage to opposite sex couples. Or perhaps the decision in Baker, coming just five years after Loving $v$. Virginia, ${ }^{263}$ offers contemporaneous evidence of how the Court understood the scope and implications of its Loving decision. If so, however, these are matters the Court should address in a reasoned opinion, following plenary briefing and extended deliberation, without the constraints of stare decisis.

More broadly, our discussion of Baker calls into question the principle of Hicks $v$. Miranda, treating summary affirmances and dismissals as binding precedent entitled to stare decisis effect. ${ }^{264}$ Applying stare decisis in such circumstances prevents lower courts from giving full consideration to legal questions resolved in haste by the Supreme Court. The decision to address an issue summarily, without a written opinion, shows that the Court gave the question relatively short shrift. Just as we do not accord precedential weight to a denial of certiorari, the Court should abandon Hicks and deny controlling force to unexplained summary dispositions. Such opinions could be taken into account as persuasive authority, but not in a way that constrains plenary reflection on legal arguments treated in a cursory fashion by the Supreme Court. In this situation, the value of allowing thorough consideration of a legal question outweighs any enhanced legal stability that flows from requiring lower courts to decipher unexplained rulings and treat them as binding authority.

\section{B. Supervisory Liability Under Ashcroft v. Iqbal}

Much attention has been paid to the Supreme Court's recent decision in Ashcroft v. Iqbal, ${ }^{265}$ a potentially far reaching opinion on pleading requirements under Federal Rule of Civil Procedure 8. ${ }^{266}$ Some observers believe the opinion also set a major precedent on a second issue-the scope of liability for supervisory personnel sued

263388 U.S. 1 (1967) (invalidating state law prohibiting interracial marriage).

264 See supra notes 194-98 and accompanying text.

265129 S. Ct. 1937 (2009).

266 See generally Robert G. Bone, Plausibility Pleading Revisited and Revised: A Comment on Ashcroft v. Iqbal, 85 Notre Dame L. Rev. 849 (2010) (discussing the "twopronged approach" Iqbal adds doctrinally to Twombly); Comment, Pleading Standards, 123 Harv. L. Rev. 252, 253 (2009) (suggesting Iqbal subtly strengthened the plausibility standard, effectively adding a probability requirement). But see David L. Noll, The Indeterminacy of Iqbal, 99 GEO. L.J. 117 (2010) (arguing Iqbal may be less significant than some commentators suggest). 
\begin{tabular}{lllll}
\hline |yciprod01 productnLNWDLl87-4WNDL402.txt & unknown & Seq: 48 & 29-MAY-12 & 12:28 \\
\hline
\end{tabular}

when their subordinates commit constitutional violations. ${ }^{267}$ The dissenters in Iqbal claimed that the majority had completely eliminated any theory of "supervisory liability," defined as a supervisor's legal accountability "under certain conditions, for the wrongdoing of his subordinates." 268 The principal dissent took particular exception to the majority's decision "to proceed without briefing and argument" on the supervisory liability question, ${ }^{269}$ and contended that Iqbal s discussion of supervisory liability was unnecessary in that it had no apparent impact on the outcome of the case. ${ }^{270}$ I agree with the dissent's suggestion that the majority's statements regarding supervisory liability may constitute dicta, given the Court's analysis of the pleadings. In any event, to the extent there was a holding on the issue of supervisory liability, a later Court could fairly choose to read the Iqbal precedent narrowly in light of the minimal briefing on the question.

The Iqbal litigation involved claims brought by a Muslim citizen of Pakistan under Bivens v. Six Unknown Named Agents of Federal Bureau of Narcotics. ${ }^{271}$ Iqbal contended that federal officials violated the Constitution, following the September 11, 2001 terrorist attacks, when they detained him on immigration-related charges, held him in a restrictive form of custody and subjected him to beatings and other mistreatment, while investigating whether he had any connection to the terrorists. ${ }^{272}$ The Supreme Court's opinion in Iqbal addressed whether the complaint stated a claim against two high ranking federal officials, Attorney General John Ashcroft and FBI director Robert Mueller, sufficient to survive their assertion of a qualified immunity defense. ${ }^{273}$

The central allegations directed at Ashcroft and Mueller were that they " "knew of, condoned, and willfully and maliciously agreed to

267 See Richard Frankel, The Failure of Analogy in Conceptualizing Private Entity Liability Under Section 1983, 78 UMKC L. Rev. 967, 988 (2010) ("Although Iqbal has received significant attention for its potential effect on notice pleading, it also may have significant implications for the doctrine of supervisory employee liability under $\S 1983$ and Bivens."); Sheldon Nahmod, Constitutional Torts, Over-Deterrence and Supervisory Liability After Iqbal, 14 Lewis \& CLARK L. Rev. 279, 280 (2010) (“Ashcroft v. Iqbal is obviously an extremely important federal pleading decision. But it is significant for another, perhaps less obvious, reason: the Court's conditioning of supervisory liability under both $\S 1983$ and Bivens_- Iqbal involved Bivens-type claims-on constitutional violations by supervisors themselves." (footnotes omitted)).

268 Iqbal, 129 S. Ct. at 1957 (Souter, J., dissenting).

$269 I d$. at 1958.

270 See id.

271403 U.S. 388 (1971).

272 See Iqbal, 129 S. Ct. at 1943-44.

273 See id. at 1942-43. 
subject' [Iqbal] to harsh conditions of confinement 'as a matter of policy, solely on account of [his] religion, race, and/or national origin and for no legitimate penological interest.'" 274 The majority analyzed Iqbal's complaint in light of the pleading standards of Bell Atlantic Corp. $v$. Twombly, ${ }^{275}$ which requires allegation of facts sufficient to "state a claim to relief that is plausible on its face." 276 To the extent Iqbal challenged high-level policy decisions made by Ashcroft and Mueller, the majority rejected some of the complaint's allegations as "conclusory." 277 The nonconclusory factual allegations, such as the claim that thousands of Arab Muslim men were detained during the September 11 investigation, did not plausibly show a policy of purposeful discrimination under Twombly.278 This was true, the majority believed, because a "more likely" and "obvious" explanation existed for the disproportionate detention of Arab Muslims; given that the hijackers, the leader of al Qaeda, and a large segment of the organization were Arab Muslims, a disparate impact could be expected to flow from a "nondiscriminatory intent to detain aliens who were illegally present in the United States and who had potential connections to those who committed terrorist acts." 279

The Iqbal majority acknowledged that "[r] espondent's account of his prison ordeal could, if proved, demonstrate unconstitutional misconduct by some governmental actors." 280 The complaint identified "discrete wrongs-for instance, beatings-by lower level Government actors" that "if true, and if condoned by petitioners, could be the basis for some inference of wrongful intent on petitioners' part." 281 Applying Second Circuit precedent, the Court of Appeals in Iqbal had identified various ways in which supervisory personnel may be held liable under Bivens:

The personal involvement of a supervisor may be established by showing that he (1) directly participated in the violation, (2) failed to remedy the violation after being informed of it by report or appeal, (3) created a policy or custom under which the violation occurred, (4) was grossly negligent in supervising subordinates who committed the violation, or (5) was deliberately indifferent to the

274 Id. at 1951 (second alteration in original) (quoting First Amended Jury Complaint at 17-18, Iqbal, 129 S. Ct. 1937 (04 CV 1809 (JG) (JA)).

275550 U.S. 544 (2007).

276 Id. at 570.

277 Iqbal, 129 S. Ct. at 1951.

278 See id.

279 Id.

$280 \quad I d$. at 1942.

281 Id. at 1952. 
rights of others by failing to act on information that constitutional rights were being violated. ${ }^{282}$

In addition to Iqbal's challenge to the policies implemented by Ashcroft and Mueller, therefore, the majority had to consider whether the complaint stated a claim that might render those defendants liable based on the unconstitutional acts of subordinate federal officials.

The majority started with respondent's concession that "Government officials may not be held liable for the unconstitutional conduct of their subordinates under a theory of respondeat superior." 283 From there, the majority reasoned that "[b]ecause vicarious liability is inapplicable to Bivens and $\S 1983$ suits, a plaintiff must plead that each Government-official defendant, through the official's own individual actions, has violated the Constitution." ${ }^{284}$ Indeed, the majority thought the term "supervisory liability" a "misnomer": "Absent vicarious liability, each Government official, his or her title notwithstanding, is only liable for his or her own misconduct." ${ }^{85}$ Applying this principle to a discrimination claim, the majority thought allegations that a supervisor knew of discriminatory conduct by his subordinates would not suffice. Discriminatory "purpose rather than knowledge is required."286 Accordingly, "petitioners cannot be held liable unless they themselves acted on account of a constitutionally protected characteristic. Yet respondent's complaint does not contain any factual allegation sufficient to plausibly suggest petitioners' discriminatory state of mind." 287

The dissenters argued that the majority's conclusion need not follow from its premises. The majority's analysis, according to Justice Souter,

rests on the assumption that only two outcomes are possible here: respondeat superior liability, in which "an employer is subject to liability for torts committed by employees while acting within the scope of their employment," or no supervisory liability at all. The dichotomy is false. Even if an employer is not liable for the actions of his employee solely because the employee was acting within the scope of employment, there still might be conditions to render a supervisor liable for the conduct of his subordinate. ${ }^{288}$

282 Iqbal v. Hasty, 490 F.3d 143, 152 (2d Cir. 2007), rev'd 129 S. Ct. 1937 (2009).

283 Iqbal, 129 S. Ct. at 1948.

284 Id.

285 Id. at 1949.

$286 I d$.

287 Id. at 1952.

288 Id. at 1958 (Souter, J., dissenting) (citation omitted) (quoting Restatement (Third) of Agency $§ 2.04$ (2005)); see also Frankel, supra note 267, at 990 ("As the 
The dissent noted that the lower courts had applied "quite a spectrum of possible tests for supervisory liability," including some mentioned by the Second Circuit, and complained that "we have received no briefing or argument on the proper scope of supervisory liability, much less the full-dress argument we normally require."289

If the Supreme Court takes a future case concerning the liability of supervisory federal officials under Bivens or supervisory state officials under 42 U.S.C. $\S 1983$, would the Court be bound by the Iqbal opinion and, if so, what legal propositions does the opinion establish? At the very least, the Iqbal opinion would seem to include dicta to the extent it purports to rule on the scope of supervisory liability of state officials under $\S 1983$. While Bivens and $\S 1983$ are sometimes interpreted in tandem, the latter is a statutory cause of action while the former has been implied by courts as a matter of federal common law. ${ }^{290}$ The language or history of $\S 1983$ could compel results on the supervisory liability question at odds with the outcome applicable to federal officials under Bivens. ${ }^{291}$ Consequently, Iqbal would seem an inappropriate vehicle for definitive resolution of the supervisory liability issue under $\S 1983$.

With respect to the scope of supervisory liability under Bivens, the dissent makes a reasonable argument that the Iqbal majority's "conclusion ha[d] no bearing on its resolution of the case."292 A major point of difference between the majority's analysis and that of some lower courts concerned the mental state required to establish the liability of supervisory personnel. The Iqbal majority seemed to indicate that a supervisor's knowledge of unconstitutional discrimination by a subordinate cannot give rise to liability unless the supervisor himself engaged in purposeful discrimination-in other words, unless the supervisor's response to the subordinate's discrimination itself violated the Constitution. ${ }^{293}$ Some lower courts, on the other hand, including the Second Circuit in this case, have indicated that supervisors may be held liable based on a lesser mental state, such as gross negligence, deliberate indifference, or knowledge of unconstitutional

dissent pointed out, there is a significant difference between the traditional form of respondeat superior liability rejected in Monell and the supervisory liability rejected in Iqbal.").

289 Iqbal, 129 S. Ct. at 1957-58 (Souter, J., dissenting).

290 See Nahmod, supra note 267, at 303 (contending that arguments from language and legislative history of $\S 1983$ would not apply to federal common law action under Bivens).

291 See id. at 298-303.

292 Iqbal, 129 S. Ct. at 1958 (Souter, J., dissenting).

293 See id. at 1949; Nahmod, supra note 267, at 291. 
activity combined with a failure to respond. ${ }^{294}$ As Justice Souter persuasively noted, " $[\mathrm{t}]$ he majority says that all of the allegations in the complaint that Ashcroft and Mueller authorized, condoned, or even were aware of their subordinates' discriminatory conduct are 'conclusory' and therefore are 'not entitled to be assumed true." "295 Consequently, the majority's discussion of the mental state required for supervisory liability would seem to have no bearing on the outcome of the case. None of the allegations deemed nonconclusory by the majority showed a mental state that could have given rise to supervisory liability under the prevailing tests in the lower courts. On this ground, the majority's statements concerning supervisory liability might reasonably be classified as nonbinding dicta, even with respect to an action under Bivens. ${ }^{296}$

Even if one thought Iqbals discussion of supervisory liability should be read to embrace some holding, ${ }^{297}$ there remains the question of how broadly that holding should be read. The dissent's complaint about the absence of briefing and argument becomes relevant here. If the briefing really was inadequate, a future Court might reasonably apply an analysis like that in Heller, where the majority narrowly construed Miller's Second Amendment holding because of the one-sided and cursory briefing available to the Court. ${ }^{298}$

Examining the parties' briefs in Iqbal, the principal dissent appears to engage in a bit of hyperbole when it claims that "we have received no briefing or argument on the proper scope of supervisory

294 See Nahmod, supra note 267, at 293; supra text accompanying note 282.

295 Iqbal, 129 S. Ct. at 1958 (Souter, J., dissenting).

296 See Nahmod, supra note 267, at 292 (suggesting dissent was probably "attempting to render as dicta" the majority's discussion of supervisory liability).

297 One could take the position, for instance, that the majority's discussion of supervisory liability, though not outcome determinative, formed a logically "necessary" foundation for consideration of the pleading issues the Court took up in Iqbal. In order to decide whether the complaint stated a claim against Ashcroft and Mueller, it made sense to first "tak[e] note of the elements a plaintiff must plead to state a claim of unconstitutional discrimination against officials entitled to assert the defense of qualified immunity." Iqbal, 129 S. Ct. at 1947. The dissenters believed the petitioners had conceded they could be held liable under a "deliberate indifference" standard, and that this concession should have foreclosed consideration of the supervisory liability question. See id. at 1956-57 (Souter, J., dissenting). But the concession hardly counted as a complete resolution of the supervisory liability issue, given other standards that might apply. Apart from the concession, the dissenters acknowledged that "without knowing the elements of a supervisory liability claim, there would be no way to determine whether a plaintiff had made factual allegations amounting to grounds for relief on that claim." Id. at 1956.

298 See supra notes 182-83 and accompanying text. 
liability." 299 The Brief for the Petitioners included a section of several pages under the heading, "Any Supervisory Liability Permitted Under Bivens Must Be Strictly Limited." 300 The government argued that " $[\mathrm{t}]$ he logic of Bivens ... permits high-level federal officials to be held liable only for their direct involvement in constitutional violations, or (at most) their deliberate indifference in the face of information that the rights of others are being violated."301 Relying on both precedent and policy arguments, the government critiqued Second Circuit case law seemingly envisioning liability where the supervisor lacked actual knowledge of wrongdoing. ${ }^{302}$

However, if the Iqbal dissenters overreached in suggesting a complete absence of briefing on supervisory liability, they do seem correct that the Court lacked the benefit of "the full-dress argument we normally require" on the supervisory liability issue. ${ }^{303}$ The government's opening brief spent only a few pages on the standard for supervisory liability. ${ }^{304}$ Rather than defending the Second Circuit case law challenged by the government, the respondent merely identified what he characterized as points of agreement with the petitioners:

[I]t is important to note the many areas of agreement among the parties as to the substantive law governing supervisory Bivens liability. First, it is undisputed that supervisory Bivens liability cannot be established solely on a theory of respondeat superior. Second, and relatedly, all agree that a supervisor must take some affirmative act (or legally actionable omission) that contributes to or causes the constitutional violation alleged by a plaintiff. Third, petitioners agree that a supervisor's knowing acquiescence to subordinates' unconstitutional conduct is enough to establish supervisory liability. Finally, if a supervisor takes affirmative steps to create a facially unconstitutional policy, to be applied by subordinates, this too will establish supervisory liability. ${ }^{305}$

Based on these purported points of agreement, respondent then sought to show that the complaint stated a claim against petitioners. ${ }^{306}$ As a result, the Court did not have the benefit of briefs arguing, for instance, that grossly negligent supervision should constitute a

299 Iqbal, 129 S. Ct. at 1957 (Souter, J., dissenting).

300 Brief for the Petitioners at 44-50, Iqbal, 129 S. Ct. 1937 (No. 07-1015).

301 Id. at 44.

302 See id. at 44-46.

303 Iqbal, 129 S. Ct. at 1957 (Souter, J., dissenting).

304 See Brief for the Petitioners, supra note 300, at 44-47.

305 Brief for Respondent Javaid Iqbal at 46, Iqbal, 129 S. Ct. 1937 (No. 07-1015) (citations omitted).

306 See id. at $46-55$. 
basis for recovery under Bivens, or the adoption of a facially constitutional policy that lends itself to unconstitutional application.

The supervisory liability issue is one on which plenary briefing might assist the Court in reaching a well considered decision. In determining the scope of a supervisor's liability under Bivens, at least two sources of law interact-the requirements of the Constitution and federal common law. ${ }^{307}$ The corresponding statutory issues under $\S 1983$ add another layer of complexity. ${ }^{308}$ Particularly since the inadequate briefing in Iqbal concerned an issue on which appellate courts have reached differing conclusions, ${ }^{309}$ it would be appropriate for a future Court to construe the precedential impact of Iqbal narrowly. For instance, the Court could view the case as simply applying wellsettled constitutional standards for equal protection liability, but leaving unresolved the issue of whether federal common law might impose prophylactic requirements on supervisory personnel going beyond the requirements imposed by the Constitution itself. ${ }^{310} \mathrm{I}$ am not arguing that the Court should necessarily reach a different result than it did in Iqbal. I merely contend that the issue is sufficiently involved that a future Court should view itself as largely unencumbered by the Iqbal precedent when parties submit plenary briefing contesting the scope of supervisory liability under Bivens or, especially, $\S 1983$.

\section{The Viability Rule of Roe and Casey}

The third issue we will examine under the law of precedent concerns the authority of states to regulate abortion prior to fetal "viability." The term "viability" refers to a stage in prenatal development when a fetus could potentially survive outside the womb with medical assistance. ${ }^{311}$ The significance of viability for state regulation of abor-

307 See Nahmod, supra note 267, at 303 (arguing that the Court could have reached a different conclusion in Iqbal based on federal common law, but instead adopted a constitutional approach).

308 See id. at 298-303 (discussing relevant language and legislative history of $\S 1983)$.

309 See id. at 292-93 (opining that it is "surprising from a process perspective" that the majority ruled without briefing and argument and "particularly troubling" because most circuit courts had adopted a different approach).

310 See Iqbal, 129 S. Ct. at 1949 (“[R] espondent believes a supervisor's mere knowledge of his subordinate's discriminatory purpose amounts to the supervisor's violating the Constitution.").

311 See Roe v. Wade, 410 U.S. 113, 160 (1973) (discussing "the interim point at which the fetus becomes 'viable,' that is, potentially able to live outside the mother's womb, albeit with artificial aid”). 
tion derives from the Supreme Court's decision in Roe v. Wade. ${ }^{312}$ Roe indicated that states may only regulate to protect fetal life after the fetus becomes viable. ${ }^{313}$

Decisions since 1989 show a gradual diminution of the significance attributed to fetal viability in the Supreme Court's abortion jurisprudence. In Webster v. Reproductive Health Services, ${ }^{314}$ even though the trial court found that viability does not occur until twenty-three and a half or twenty-four weeks into pregnancy, a splintered majority upheld a Missouri statute that created a presumption of viability at twenty weeks and required a physician to order additional tests if necessary to make a viability determination. ${ }^{315}$ Three years later, the controlling plurality opinion in Planned Parenthood of Southeastern Pennsylvania v. Casey ${ }^{316}$ reaffirmed the viability rule in dicta, but in a significantly diluted form. The Casey plurality acknowledged a state interest in protecting fetal life from the outset of the pregnancy-not just after viability as the Court had indicated in Roe-and permitted previability regulations so long as they do not create an "undue burden" on abortion rights. ${ }^{317}$ More recently, in Gonzales v. Carhart, ${ }^{318}$

312 See id. at 163-64.

313 See id. ("With respect to the State's important and legitimate interest in potential life, the 'compelling' point is at viability. This is so because the fetus then presumably has the capability of meaningful life outside the mother's womb. State regulation protective of fetal life after viability thus has both logical and biological justifications. If the State is interested in protecting fetal life after viability, it may go so far as to proscribe abortion during that period, except when it is necessary to preserve the life or health of the mother.").

314492 U.S. 490 (1989) (plurality opinion).

315 See id. at 515 (stating that the statute "creates what is essentially a presumption of viability at 20 weeks, which the physician must rebut with tests indicating that the fetus is not viable prior to performing an abortion"). Chief Justice Rehnquist authored a three-Justice plurality opinion rejecting the lower courts' reading of the statute to require testing even if the tests would not be useful to determining viability or would endanger the mother or fetus. See id. at 514-15. The plurality thought the viability rule cast doubt on even this restricted reading of the statute, see id. at 517 , but could "not see why the State's interest in protecting potential human life should come into existence only at the point of viability, and that there should therefore be a rigid line allowing state regulation after viability but prohibiting it before viability." Id. at 519. Justice O'Connor thought the statute, as read by the plurality, could be reconciled with Roe and subsequent cases, so that no reconsideration of Roe was necessary. See id. at 525-31 (O'Connor, J., concurring in part and concurring in the judgment). The fifth vote to sustain the statute came from Justice Scalia, who thought the Court should overrule Roe outright. Id. at 532-37 (Scalia, J., concurring in part and concurring in the judgment).

316505 U.S. 833 (1992).

317 See id. passim.

318550 U.S. 124 (2007). 
the Court upheld federal legislation forbidding use of the intact dilation and evacuation method of abortion, even though the ban applied prior to fetal viability. ${ }^{319}$ While the majority "assume[d]" the continued applicability of the viability rule, ${ }^{320}$ the principal dissent accused the majority of "blur[ring] the line, firmly drawn in Casey, between previability and postviability abortions." 321

The current vitality of the viability rule will presumably be a significant issue in litigation over recent state statutes forbidding abortions after twenty weeks of pregnancy. Following the lead of Nebraska, a number of states have now prohibited most abortions after twenty weeks, arguing that a fetus at that stage of development can feel pain as a result of the abortion procedure. ${ }^{322}$ As suggested by the opinions in Webster, some fetuses protected by a twenty-week threshold will likely fall short of viability. ${ }^{323}$

If the Supreme Court accepts a case turning on the duration of abortion rights, a strong argument can be made that the Court should not consider itself bound to apply the viability rule as a matter of precedent. To begin with, the issue of the duration of abortion rights was not before the Court in Roe. The Roe litigation involved a challenge to a Texas statute that prohibited all abortions except those necessary to save the mother's life. ${ }^{324}$ Once the Court concluded that a woman has a fundamental right to terminate an unwanted pregnancy and that the states lack a compelling interest in protecting fetal life at the outset of pregnancy, the invalidity of the statute was established regardless of how far into pregnancy the right to an abortion extends. ${ }^{325}$ The validity of the Texas statute did not turn on the question of when in pregnancy a state may regulate to protect fetal life. Consequently, the Court's articulation of the viability rule constituted dictum, unnecessary to resolve the case before the Court.

319 See id. at $147,168$.

320 See id. at 146.

321 Id. at 171 (Ginsburg, J., dissenting).

322 See Monica Davey, Nebraska, Citing Pain, Sets Limits on Abortion, N.Y. Times, Apr. 14, 2010, at A16; Erik Eckholm, New Laws in 6 States Ban Abortions After 20 Weeks, N.Y. Times, June 27, 2011, at A10.

323 The viability rule might also become an issue in litigation arising from recent Oklahoma legislation forbidding sex-selective abortions. Drew Zahn, New Law Bans Picking Baby's Sex by Abortion, World Net Daily (May 23, 2009, 12:00 AM), www.wnd. com/2009/05/98886.

324 See Roe v. Wade, 314 F. Supp. 1217, 1219 n.2 (N.D. Tex. 1970) (per curiam) (quoting Texas Penal Code arts. 1191, 1196), aff'd in part and rev'd in part, 410 U.S. 113 (1973); Randy Beck, Self-Conscious Dicta: The Origins of Roe v. Wade's Trimester Framework, 51 Aм. J. Legal Hist. 505, 509-10 (2012).

325 See Beck, supra note 324 , at 512-15. 
\begin{tabular}{lllll}
\hline |yciprod01 $\backslash$ productnLNWDL187-4WNDL402.txt & unknown & Seq: 57 & 29-MAY-12 & 12:28 \\
\hline
\end{tabular}

2012]

TRANSTEMPORAL SEPARATION OF POWERS

$14^{61}$

The Court's internal deliberations in Roe confirm that the viability rule represented an attempt to resolve an issue not presented by the pending litigation. ${ }^{326}$ The files of Justice Blackmun and other retired Justices show that the viability rule did not make its way into the Roe opinion until the third draft circulated to the Court. The first draft would have invalidated the Texas statute on vagueness grounds, while the companion opinion in Doe v. Bolton ${ }^{327}$ would have recognized a constitutional right to abortion of unspecified duration. ${ }^{328}$ The second draft of Roe (following reargument of the case) rested its analysis on a constitutional right to abortion, but indicated that this right would last only through the first trimester of pregnancy. ${ }^{329}$ Justice Blackmun's cover memorandum accompanying this draft acknowledged that the opinion "contains dictum" and that the proposed first-trimester cutoff point "is arbitrary, but perhaps any other selected point, such as quickening or viability, is equally arbitrary." 330 Justice Stewart subsequently commented on this second draft of Roe, noting:

One of my concerns with your opinion as presently written is the specificity of its dictum - particularly in its fixing of the end of the first trimester as the critical point for valid state action. I appreciate the inevitability and indeed wisdom of dicta in the Court's opinion, but I wonder about the desirability of the dicta being quite so inflexibly "legislative." 331

The viability rule appeared in the third draft of Roe, replacing the first-trimester line drawn in the previous version. ${ }^{332}$ Justice Blackmun's acknowledgement that Roe's second draft included dictum, Justice Stewart's identification of the first-trimester cutoff as part of that opinion's dicta, and the fact that the third draft's shift to a viability cutoff did not alter the Court's analysis all show the majority's awareness that adoption of the viability rule was unnecessary to review of the Texas statute. Indeed, at least two other Justices in the majority made

326 See Randy Beck, Fueling Controversy, 95 MARQ. L. Rev. 735, 738-41 (2011-12).

327410 U.S. 179 (1973).

328 See Beck, supra note 324, at 517.

329 See id. at 520.

330 Id. (quoting Justice Harry A. Blackmun, Memorandum to the Conference Re: No. 70-18-Roe v. Wade (Nov. 21, 1972), in Harry A. Blackmun Papers, Library of Congress, Manuscript Division, Box 151, Folder 6 [hereinafter Blackmun Papers]); accord DAvID J. Garrow, Liberty and Sexuality 580 (1994).

331 Beck, supra note 324, at 525 (quoting Justice Potter Stewart, Memorandum re: Abortion Cases (Dec. 14, 1972), in Blackmun Papers, supra note 330); see GARrow, supra note 330, Folder 8 at 585 .

332 See Beck, supra note 324, at 525-26. 
comments in internal memoranda indicating that the Roe Court did not need to draw a line specifying the duration of abortion rights. ${ }^{333}$

Given that the duration of abortion rights was not really at issue in Roe, it is perhaps no surprise that the parties failed to brief the question. Those challenging the Texas statute denied that the state possessed a compelling interest in fetal life that would support the legislation as written but did not speculate about whether a more narrowly drawn statute might further such an interest. ${ }^{334}$ The defenders of the statute claimed a compelling state interest in protecting fetal life from the outset of pregnancy. ${ }^{335}$ The parties did not address the question of, assuming a right to abortion, how far into pregnancy it extends, and the advocates in oral argument avoided answering such line-drawing questions. ${ }^{336}$ The Roe Court therefore adopted the viability rule without the benefit of adversarial briefing or argument on the duration of abortion rights.

The lack of support for the viability rule in the Roe opinion provides an additional reason for according that line diminished precedential weight. As Justice Breyer has argued in discussing the Dred Scott opinion, "in a highly visible, politically controversial case with public feeling running high," the Court's opinion should be "principled, reasoned, transparent, and informative."337 With respect to the "highly visible, politically controversial" Roe opinion, however, scholars have long recognized that the Court utterly failed to justify the viability rule. Professor John Hart Ely explained soon after the opinion's release that Roe's discussion of viability "seem[ed] to mistake a definition for a syllogism." 338 As I sought to elaborate Ely's point elsewhere, " $[t]$ he Court failed to offer any constitutional principle connecting state regulatory power and the value of developing fetal life that-when combined with the Court's definition of viability-would entail the conclusion that the state can only prohibit abortion of a viable fetus."339 Other scholars have agreed with Ely's assessment, including Laurence Tribe, who wrote that the Roe Court "offers no

333 See, e.g., $i d$. at 516-17 (quoting Justice Brennan); id. at 522 (quoting Justice Powell); see also id. at 521 (quoting Justice Powell's clerk).

334 See id. at 511.

335 See id.

336 See id. at 511-12.

337 See Breyer, supra note 18, at 43 (discussing Dred Scott v. Sandford, 60 U.S. (19 How.) 393 (1857)).

338 John Hart Ely, The Wages of Crying Wolf: A Comment on Roe v. Wade, 82 Yale L.J. 920, 924 (1973).

339 Randy Beck, Gonzales, Casey, and the Viability Rule, 103 Nw. U. L. Rev. 249, 270 (2009). 
reason at all for what the Court has held," 340 and Christopher Eisgruber, who termed the Roe Court's defense of the viability rule "blatantly circular." 341

While the Casey plurality purported to reaffirm the viability rule, in part on the basis of stare decisis, it did not cure the defects in the Roe Court's defense of the rule. To begin with, as in Roe, the Pennsylvania regulations at issue in Casey applied from the outset of pregnancy. As a consequence, the reaffirmation of the viability rule in Casey also represented dictum, unnecessary to resolution of the issues before the Court. ${ }^{342}$ Moreover, the parties in Casey did not brief the Court on potential arguments for or objections to the viability rule. ${ }^{343}$

In attempting to justify the viability rule, the Casey plurality asserted that viability marks "the independent existence of [a] second life" that "can in reason and all fairness be the object of state protection that now overrides the rights of the woman."344 This cryptic and conclusory justification left unaddressed a host of critical questions. The plurality never explained why independence should be a necessary condition for protection by the state; why the particular form of hypothetical independence denoted by the term "viability" should be the form of independence that matters (rather than genetic independence at conception or independence of movement at quickening); or how this independent existence requirement can be derived from the Constitution. ${ }^{345}$ Consequently, Casey did not rectify Roe's failure to justify the viability rule in constitutional terms. ${ }^{346}$

In short, the viability rule falls into the category of legal rules that the Court has repeatedly invoked, and even applied, but never "squarely addressed." 347 Like the habeas corpus harmless error standard considered in Brecht and the intra-enterprise conspiracy doctrine

340 Id. at 269 (quoting Laurence H. Tribe, Forward: Toward a Model of Roles in the Due Process of Life and Law, 87 Harv. L. Rev. 1, 4 (1973)).

341 Id. (quoting Christopher L. Eisgruber, The Fourteenth Amendment's Constitution, 69 S. Cal. L. Rev. 47, 96 \& n.171 (1995)).

342 See Randy Beck, The Essential Holding of Casey: Rethinking Viability, 75 UMKC L. REv. 713, 717 (2007).

343 See id. at 718 (" $[\mathrm{S}]$ ince viability was not relevant to the constitutionality of the challenged Pennsylvania regulations, potential justifications for the viability rule played no more than a de minimis role in the parties' briefs.").

344 Planned Parenthood of Se. Pa. v. Casey, 505 U.S. 833, 870 (1992).

345 See Beck, supra note 339, at 275-76.

346 See id. at 276. The Court's subsequent opinion in Gonzales, permitting states to afford some legal protection to a previable fetus, makes a plausible constitutional justification for the viability rule even more difficult to envision. Id. at 276-79.

347 See supra notes 222-33 and accompanying text. 
addressed in Copperweld, ${ }^{348}$ the Court should not view the viability rule as binding precedent precluding future examination of the duration of abortion rights on the basis of plenary briefing and argument. To be binding on future Courts, a ruling on a matter of such consequence as the duration of the constitutional right to abortion should be the product of careful deliberation and adequate justification in a case where the ruling matters to the outcome of the litigation. Absent these conditions, the viability rule does not warrant treatment as binding precedent entitled to adherence as a matter of stare decisis.

\section{CONCLUSION}

The judiciary's power to establish precedent serves important functions, making the law more stable and enhancing its ability to influence conduct. But our system has always distrusted excessive concentrations of power. It is not surprising, then, to find that the power conferred on precedent-setting courts is qualified and limited, and that the law of precedent empowers later judges to ignore or limit the reach of opinions issued under suboptimal decisionmaking conditions. These limitations on the rule of stare decisis allow later judges to check the authority of their predecessors and help to confine the precedent-setting power to those situations where it can be exercised most responsibly.

348 See Brecht v. Abrahamson, 507 U.S. 619, 631 (1993); Copperweld Corp. v. Indep. Tube Corp., 467 U.S. 752, 766-67 (1984). 